\title{
Poemele homerice în veșminte românești. O analiză diacronică (II)
}

\author{
Petre Gheorghe Bârlea* \\ Facultatea de Litere, Universitatea „Ovidius”, Aleea Universității 1, 900472 Constanța, România
}

\author{
Despre articol \\ Istoric: \\ Primit 6 octombrie 2015 \\ Acceptat 25 octombrie 2015 \\ Publicat 12 februarie 2016 \\ Cuvinte-cheie: \\ traducere \\ limbă literară \\ diacronie \\ fonomorfologie \\ echivalări lexico-semantice \\ localizare
}

\begin{abstract}
Rezumat
În acest articol continuăm analiza diacronică a versiunilor românești ale poemelor homerice, cf. Bârlea (2015c). Se păstrează tripla perspectivă a abordării: a) evoluția studiilor homerice internaționale, care facilitează ediții tot mai detaliate și mai exacte ale textelor homerice; b) evoluția limbii române literare în perioada vizată (1837-2012), cu unele referiri la perioade mai vechi; c) diferențele de opțiuni traductologice. De data aceasta, avem în vedere domenii pe cît posibil distincte din structura limbii traducerilor-aspectele fonomorfologice și aspectele lexicosemantice. O atenție specială este acordată localizărilor lingvistice, strîns legate de mentalitățile și realitățile istorice ale spațiului românesc în care circulă aceste traduceri succesive din opera lui Homer. În primul caz, am vizat mai ales problemele de grafie și accent, iar în al doilea, am avut în vedere nu numai repartizarea diacronică a formelor și sensurilor cuvintelor, ci și dispunerea diastratică și diatopică.
\end{abstract}

\section{Grafia și fonetismul}

1.1. De la notarea numelor de personaje, locuri, obiecte, pînă la îmbinările de cuvinte uzuale, particularitățile privind grafia, accentul și, în general, echivalările fonomorfologice în română au contribuit vizibil la reușita sau nereușita ansamblului traducerilor din opera lui Homer dăruite culturii moderne. Nu numai versiunile vechi, redactate cu caractere chirilice sau de tranziție, dar și cele ulterioare au recurs la forme precum Ermia pentru Hermes, Efest pentru Hefaistos, Evripil pentru Eurypylos sau Tetis - transcriere valabilă atît pentru numele mamei lui Ahile, nereida Thetis, cît și pentru al lui Tethys, soția lui Oceanos.

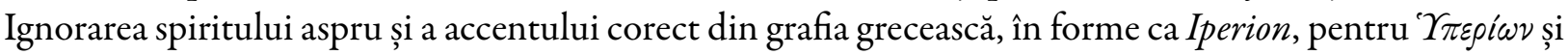
folosirea africatelor $c e, c i$, inexistente în greacă, pentru nume ca Forkys, Okeanós, au devenit, de asemenea, obișnuințe în traducerile românești. Unele subtilități nici nu puteau fi respectate pînă la capăt în formele românești versificate: Abile / Abiléu, Odysséu / Odýsseu aveau accente mobile chiar și în textul original.

1.2. Și mai vizibile sînt schimbările de accent în română datorate exclusiv rigorilor metrice, de astă dată. Cînd o formă precum într-àrmă a fost criticată la GM, s-a avut în vedere îndrăzneala modificării morfolexicale, dar termenul a șocat și prin schimbarea de accent, desigur. Forma uzuală, inarmează, nu s-ar fi încadrat însă nicicum în vers. Asemenea licențe segmentale și suprasegmentale apar peste tot în română, inclusiv în echilibrata versiune CP sau în savanta DS. La cel dintîi, s-a remarcat frecvența adverbului apoi, folosit la început de vers, ca un conector multifuncțional. Or, această poziție arată că el trebuie citit ápoi, deoarece nu poate avea decît structură trohaică. Prin extensie, forma astfel adaptată accentual se regăsește și în interiorul unor stihuri, ceea ce nu mai era deloc acceptabil. În versiunea DS, schimbarea accentului, operată concomitent cu cea morfolexicală, ajută, de asemenea, la asigurarea curgerii naturale a versului: cu-aleasă fagádă (DS-I, XXI, 99); Troienii cei trùfaşi (DS-I, XXI, 55). Uneori, în context, un cuvînt uzual își pierde de tot accentul natural, preluat de cuvintul monosilabic anterior, care cată să fie prima subunitate a piciorului metric respectiv: dară nù-l putu sparge (DS-I, XXI, 164).

*Adresă de corespondență: gbarlea@yahoo.fr. 
Petre Gheorghe Bârlea

1.3. În numeroase alte cazuri, schimbările de structură fonetică nu sînt explicabile ratione metrica, ci țin de sursa folosită, de convențiile epocii din istoria limbii și culturii române și, nu în ultimul rînd, de opțiunile strict personale ale traducătorilor: G. Coșbuc scrie Atene, și nu Atena sau Athena, numai pentru că

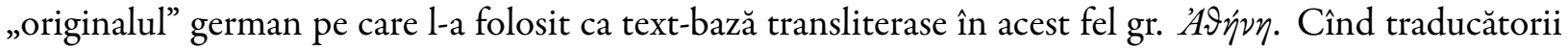
moderni au început să redea pronunția reconstituită din original, precum Chaos, gestul a fost taxat drept tentativă de întoarcere la etimologism, prin raportare la sistemul scrierii fonologice din română. Justificate au fost criticile aduse unor forme accentuale aberante (îmi dèteși, raspấnde, guvèrnă, se-n-creàstă și multe altele asemenea - la GM), deși modificări de accent, mai ales în formele conjuncte, apar chiar și în cele mai îngrijite versiuni românești, cf. pe care-i ucis-am, la DS. Altfel, unele „barbarisme” au fost unanim acceptate, mai ales în onomastică, și se întîlnesc pînă în edițiile din 2012, avînd în vedere că ele s-au fixat definitiv în uzul limbii române - Egist, Elena, Fedra (Ds-I, p. 401).

1.4. Adăugăm aici-în treacăt, deocamdată—problema efectelor eufonice din scenele de luptă și din alte pasaje. Ele trebuie discutate pe larg într-un capitol destinat elementelor pragmatico-stilistice. În mod obiectiv, asemenea sugestii sînt mai greu de sesizat în original, iar cele clar vizibile sînt palid redate în primele versiuni românești (dar și în cele din alte limbi, de altfel), căci părea că lipsesc mijloacele de echivalare. Pe măsură ce edițiile academice de text au inclus în aparatul critic tot mai multe semnalări ale specialiștilor cu privire la rafinamentele stilistice de acest tip, au evoluat și variantele literare ale limbilor primitoare. În română, imaginile bazate pe timbru imitativ au devenit adevărate probe de virtuozitate începînd cu G. Coșbuc și G. Murnu, traducătorii homerizi ai noului secol. La exemplul care redă $I l$., XVII, 50 și 56-57, s-ar putea adăuga alte cîteva zeci, bine întocmite în română, pînă la Dan Slușanschi.

Se prăbuşi, greu bufnind - zuruiră pe el grele zale,

..............................

Vinturi vuind de prin zäri...

Dară, bătînd viforos, vine vîntul cu vaier, furtună.

(Ds-I, XVII, 50; 56-57)

De obicei, dacă nu se găsește sintagma sinestezică, multiplele sugestii homerice-vizuale, auditive, dinamice-se redau prin notații succesive, bine încatenate, totuși, în structura versului:

...iar pe trupu-i arama sclipindă

Greu zurui și cumplit, cum, ferindu-se el într-o parte,

Tot alerga, cînd acela-l urma cu vuinde vîrtejuri.

(Ds-I, XXI, 254-256)

1.5. Spiritul inovator față de limba română s-a manifestat și în privința grafiei structurilor morfosintactice, foarte clar delimitate lexical în limba română actuală. Le găsim mai frecvent la începuturi, date fiind absența normelor ortografice și dificultățile imprimării tipografice (cecauți aci; să vezi amea necinste, cémia făcut Atrid; fatal'alui trufie ș.a.m.d., CA-I, I, 221-224 / p. 10). Unele, inevitabile, apar și la CP sau DS (deolaltă, deodat'). Asemenea inovații devin supărător de frecvente la GM, căci se încadrează în avîntul creator rectificator pe toate fronturile, manifestat de homerologul en titre al unei mai bine de jumătăți de veac din istoria limbii române literare. Nu numai necruțătorul critic V. Eftimiu, ci chiar comilitonii lui George Murnu îi atrag atenția asupra unor forme de tot inacceptabile față de norma academică, dar și faţă de vorbirea uzuală, norme deja unanim acceptate la vremea lansării inovațiilor murniene: dupolaltă, întreolaltă, pesteolaltă, lîngăolaltă, laoparte; învremece, dasta, măcarcăa, pînăce, de treiori ș.a. (cf. Herescu, 2011, p. 373-375, 381)2.

\footnotetext{
${ }^{1}$ Se cuvine să ne amintim că G. Coșbuc a fost poetul care a furnizat exemplul clasic de aliterație în tratatele și manualele de stilistică a limbii române (Prin vulturi, vîntul viu vuia...).

${ }^{2}$ De precizat că, înainte de a deveni apărătorul și elogiatorul oficial al lui GM, Herescu criticase aceste forme într-o recenzie de care pare să fi uitat (Herescu, 1929, p. 68-70).
} 


\section{Lexic și semantică}

2.1. Forma și semnificația cuvintelor din tălmăcirile românești au constituit, în mod firesc, nivelul cel mai vizibil și mai mult supus evaluărilor din istoria receptării moderne a textelor homerice. La capătul analizei noastre privind atît textele propriu-zise, cît și cele de întîmpinare și evaluare în timp, putem spune că se conturează o evoluție de tip spirală a reușitelor echivalării în acest sens. De la efortul respectării termenului sau sintagmei din original, în româna încă nefixată în cadre literare exersate (C. Aristia, I. Caragiani), pînă la scrupulele filologice îmbinate cu harul poetic al vremii din urmă (Hâncu-Diamandescu, dar, mai ales, D. Slușanschi), vibrațiile arcului răsucit în sus au fost provocate de îndrăznelile poetice ale unor G. Coșbuc și, mai ales, G. Murnu ori strunite de minimalismul lui E. Lovinescu și echilibrul lui C. Papacostea.

Selecția lexicală, deloc ușoară într-un text de o asemenea factură, a urmat cîteva direcţii dominante.

2.2. Invenția lexicală se impunea de la sine, avînd în vedere diferențele de cultură, civilizație și mentalitate, accentuate de distanța în timp dintre utilizatorii celor două limbi.

a) Încă de la începuturi, traducătorii români au avut de rezolvat problema compuselor prin sudare (adjectiv + substantiv etc.) din epitetele „permanente” homerice. Unele echivalări s-au dovedit inspirate şi au

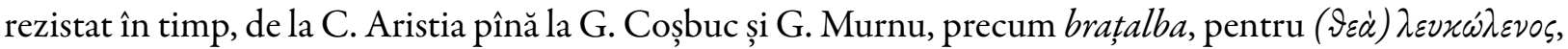
adică pentru Hera, soția lui Zeus. Este drept că, altfel, epitetul ar fi greu de încadrat chiar și în hexametrul dactilic catalectic românesc și, practic, imposibil în endecasilabul iambic ritmat în octave (de tip Ariosto) din GC sau în endecasilabul alb din versiunea GM. Numai în proză au fost posibile transpunerile firești pentru limba română - (cea) cu brațe albe. La fel, generațiile mai recente au preluat de la traducătorii din secolul al XIX-lea formule ca regii păstori de popoare, pedestraşii stavilă-n bătaie, cu firești variații personale, cf. GM - stavilă; zid la război; HD - zăgaz primejdiei. Alte asemenea calcuri morfolexicale nu au rezistat (argint-arcatul, de nalt tunătorul, încofrații). De altfel, C. Aristia însuși alternează compusele cu funcție apozițională, obligat de context: de pildă, ped-agerul, dar și depicior iute, pentru Ahile. Formula din urmă a fost definitiv asimilată, nu fără nuanțări-cel iute depicior, la GM și la toți urmașii săi-și nu fără încercări nereușite de alternare, precum şoimanul Abile, la același GM. Dar despre epitetele permanente și ornante vom mai avea ocazia să vorbim...

b) Multe alte tipuri de cuvinte și sintagme au provocat căutări laborioase în tezaurul limbii primitoare sau, la nevoie, au impus creativitatea personală a traducătorului. I. H. Rădulescu credea că pentru lexicul uzual este relativ ușor să-i spui mersului - mers, sabiei - sabie, brațului - braț, și că doar numele și epitetele zeităților ridică probleme într-o astfel de traducere (I. H. Rădulescu, Editorul, în CA-I, p. VIII). În realitate, pentru a-l reda pe Homer „în ființa lui”, chiar și cele mai banale cuvinte trebuie alese cu grijă. Sabia din exemplul dat face parte dintr-o anumită arie terminologică și, în plus, cuvîntul generic nu acoperă totdeauna tipul respectiv de armă, căci nu erau concepute la fel și nu arătau la fel în dotarea militară a celor două popoare. Și, mai simplu, orice cuvînt este pretabil la selecții speciale dintr-o serie sinonimică. Exemple se află cu miile în textele despre care vorbim aici. Ne vom referi, pentru moment, numai la cel mai cunoscut.

Astăzi, ni se pare că primul vers din Iliada nu putea să sune în română altfel decît îl cunoaștem cu toții:

Cîntă, zeiță, mînia ce-aprinse pe-Ahil Peleianul (GMD-I, I, 1)

Formula îi aparține lui G. Murnu și a fost preluată, în semn de omagiu, de către D. Slușanschi, căci devenise, oarecum, „,sacramentală” (DS-I, p. 510), fie și numai prin larga răspîndire a versiunilor GM. Nu s-a ajuns uşor la ea, însă. În prima traducere de notorietate în spațiul lingvistic românesc, cea aparținînd lui Aristia, din 1837, versul—foarte fidel față de original—suna astfel: 
Aristia explică pe larg, în nota corespunzătoare, alegerea vocativului Zee: zînă nu putea fi, căci $\Theta \varepsilon \dot{\alpha}$ înseamnă mult mai mult în ierarhia Olimpului, este „zeiță”; dar zeiță îi suna în româna epocii ca Zoița; Zeă era „neregulat” și „urît” fonetic, Zeo suna ca Stano; așadar, rămînea doar Zee, prin care a vrut să „rumănească” termenul, căci „Deus, dea face zeu, zee”, răspunzînd clar femininului lui Zeu (CA-I, p. 31).

Apoi, trebuie să reamintim că nici G. Murnu nu a avut dintr-o dată inspirația providențială care l-a ajutat să dăltuiască în marmură românească arhicunoscutul vers grecesc. În celebra ediție din 1920, care valorifica două decenii de eforturi și asigura, pentru prima dată, depline drepturi de cetate în cultura națională a strămoșului poeziei universale—căci era o traducere integrală, elegant tipărită, ilustrată și răsplătită cu Premiul cel Mare al Academiei Române-, invocația relua tocmai vocativul ocolit de predecesorul paşoptist, dar într-o variantă populară, cît se poate de nefericită:

Cîntă, zeițo... (GM-I, I, 1)

Să nu fi citit Murnu textul lui Aristia? Chiar dacă acesta din urmă fusese criticat de mulți cititori profesioniști, culminînd cu N. Iorga, explicaţiile sale sînt dovezi de bun simţ, iar versiunea sa din 1837 rămîne fondatoare. Opțiunea inițială (1920) a lui Murnu a fost prompt și necruțător semnalată ca dovadă a deprecierii lexicale a textului homeric, exact în termenii deja cunoscuți: „Zeițo sună ca Joițo” (Eftimiu, 1996 , p. 253) $)^{3}$. Vocativul cu pricina a fost schimbat în ediţiile ulterioare, zeiță rămînînd emblematic pentru haina românească a incipitului Iliadei. Între timp însă, au existat și alte conjecturi, propuse de toți cei care s-au încercat în transpunerea versului homeric. Proba cronosului, respectiv evoluția limbii române literare a validat definitiv varianta „vocativ = nominativ”, de tip latinesc.

Dar acesta este numai unul dintre cele cinci cuvinte ale primului vers din Iliada, devenite opt în ro-

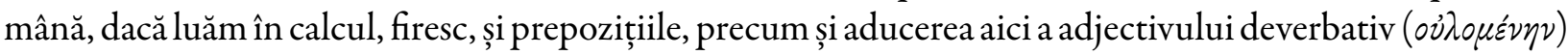
din stihul secund al originalului:

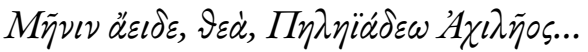

Multe căutări a presupus și echivalarea epitetului pentru Ahile, în cadrul permanentei probleme a canonului formular deja mult discutat în aceste pagini. Reluăm aici numai două dintre soluţiile propuse. Astfel, dintre cele relativ recente, versiunea în proză HD respectă tiparul frazei homerice, evitînd dislocarea operată de Murnu. Rezultatul este un enunț corect, fidel unității sintactice homerice, dar fără strălucirea versului consacrat în română:

\section{Cîntă, zeiţă, mînia Peleidului Abile (HD-I, I, 1)}

Într-o traducere care o precedă cu puțin pe aceea a lui D. Slușanschi, clasicistul Nicolae Georgescu oferă o altă reorganizare a propoziției propuse de dascălul său, cu schimbarea de rigoare a epitetului patronimic:

Cîntă zeiță, de-Abile Pelidul cu furia-i oarbă... (cf. Georgescu, 2005, p. 31)

Obține, astfel, un vers armonios cadențat, bine integrat atît în metrica și prozodia originalului, cît și în acelea ale limbii beneficiare, dar cu prețul multiplicării unităților lexicale, de la cinci, la nouă. De fapt, nu aspectul cantitativ contează, ci salvarea unității originale dintre enunțul logico-sintactic și tiparul cadenței sonore.

Lecțiunea NG ne trimite însă la un alt cuvînt, din același vers, generator de ostenitoare căutări în laboratoarele traducătorilor români. Este vorba despre termenul cu care se deschide întreaga creație homerică, $\mu \tilde{\eta} \nu \imath \nu($ N. $\mu \tilde{\eta} \nu l \varsigma)$. Pare un cuvînt simplu, fără probleme de transpunere, mai ales că româna, ca multe alte

\footnotetext{
${ }^{3}$ Poetul, dramaturgul și gazetarul redutabil care era Victor Eftimiu nu ezită să califice această formă, pe drept cuvînt, „un vocativ familiar pînă la vulgaritate”. Odată dezlănțuită, diatriba continuă cu extragerea unor exemple similare: ochioaso, deliu, mai dihai, abraș ș.a. sînt mostre de „vulgarități de periferie, dubios colorate” (Eftimiu, 1996, p. 253).
} 
limbi balcanice, de altfel, îl moștenește ca atare chiar din greacă: „mînie” ${ }^{4}$. În realitate, ca orice termen din sfera semantică a afectelor, înțelesurile lui sînt foarte bogate, foarte nuanțate și extrem de dinamice în contextele lingvistice și extralingvistice care le valorifică ${ }^{5}$. Pentru semnificaţia din textul homeric, un tălmăcitor care știa bine ce înseamnă finețea nuanțelor lexicului afectiv—ne referim la Mihai Eminescuconsideră că mînia este o activitate în primul rînd cerebrală, și numai în al doilea rînd afectivă, ceea ce nu ar fi fost cazul în atitudinea lui Ahile, războinicul prin definiție, fără mari profunzimi spirituale, mai degrabă instinctual în reacții. Eroul grec trăia ,în supărare”, o stare mai apropiată de glasul inimii, așa încît echivalența propusă de poetul român este:

\section{Supărul cântă-mi-l, muză... (M. Eminescu, 1877) ${ }^{6}$}

N. Georgescu reia acest termen, arătînd că și latinii au tradus sintagma respectivă cu Achile furens (ca și Hercule furens). De fapt, în comentariul său, exegetul și traducătorul modern recunoaște că lat. furor nu conține zăcășenia (zăcăşia, din dicționarul lui Hasdeu) care îl caracteriza pe Ahile în acele momente. În plus, rom. furia are alt tip de accentuare (cu tendința unei duble accentuări). Cu toate acestea, îl folosește în versiunea sa, cf. supra, adăugîndu-i un atribut care să accentueze ideea eminesciană de manifestare instinctuală.

Este atît de importantă echivalarea corectă a unui cuvînt ca acesta? Este, desigur, căci el reprezintă începutul începuturilor în Iliada și în întreaga operă homerică, repetăm acest lucru. Cuvîntul de deschidere poartă în el toată încărcătura tematică a epopeii. Nu numai Proóimion-ul, nu numai prima mare unitate compozițională liniară (dintre cele două, „Mînia lui Ahile” și „Voința lui Zeus”) au ca termentemă ideea desemnată de acest cuvînt, ci întregul poem se află sub imperiul semnificației sale. Iliada este istoria poetizată a unui război, iar un război este totdeauna povestea unei mari supărări. În consecință, este foarte importantă traducerea acestui cuvânt în limbile popoarelor care vor să-și aibă Homerul lor în limba și cultura naţională ${ }^{7}$. Întrebarea de la care au pornit aceste consideraţii poate căpăta însă, mai corect, un alt răspuns: toate cuvintele și toate îmbinările lor în text sînt importante, în felul lor. Atîta cît se poate reconstitui din procesul făuririi versiunilor studiate aici, cuvinte cu aparență mult mai banală au provocat mari frămîntări în mintea și în sufletele acestor bijutieri ai cuvîntului. Problemele selecției vizează nu numai termenii referitori la personajele divine sau umane și la epitetele lor, nu numai termenii-cheie, ci orice alt tip de cuvinte din text ${ }^{8}$.

\footnotetext{
${ }^{4} \mathrm{Nu}$ insistăm aici asupra istoriei cuvîntului în română. Semnalăm, în schimb, faptul că celebrele „liste de cuvinte homerice regăsibile în limba noastră” (id est: albaneză, bulgară, croată, macedoneană, sîrbă ș.a.) -liste care circulă mai ales în mediul virtual, electronic, dar sînt preluate din tratatele academice de lingvistică din țările respective, ca un certificat de vechime și, prin urmare, de noblețe-încep aproape sistematic cu acest cuvînt. Ismail Kadare îl pune în gura unor personaje din romanul Dosarul H, ca emblematic pentru conflictele ce marchează de milenii istoria poporului său (cf. Bârlea, 2015b, p. 46-49).

${ }^{5}$ Pentru caracteristicile acestui cîmp semantic, cf. Stoica (2012).

${ }^{6}$ M. Eminescu a tradus în metru original cîntul I, vv. 1-18 din Iliada cam în anii 1877-1878, cf. B.A.R., Mss. rom. 2281, f.a., cf. și Mss. B.A.R. 2306, 96; 2308, 1. Textul intitulat Din Iliada a fost publicat de către D. Murărașu, după mai bine de o jumătate de secol, în revista „Făt-Frumos”, Suceava, VII, nr. 3-4, 1932, p. 118, apoi este reluat de Perpessicius în volumul de postume și anexe al monumentalei serii Eminescu, 1952, p. 515, cu variantele autorului (șapte pagini din caietul manuscris 2266 numai pentru primele cinci versuri din Iliada!) și cu notele editorului în Eminescu, 1958, p. 597. În aceleași volume și cu aceeași distribuție a materialului se află și cele 18 versuri traduse sub titlul Din Odisseia, reprezentînd începutul respectivului poem.

${ }^{7} \mathrm{Nu}$ ne-am propus aici să ne substituim exegeților, dar, din perspectiva traductologiei, trebuie amintită semnificația cu totul specială a cuvîntului în mentalitatea şi vorbirea lumii homerice: $\mu \tilde{\eta} v \iota \varsigma$ înseamnă „mînie divină, funestă” și Platon enumeră patru variante de manifestare concretă (provocate de Apollo, de Dionysos, de Muze, de Afrodita sau Eros, cf. Platon, Phaidros, 244a-245c). Primul vers al invocației din Iliada e singurul loc din tot corpusul lexical homeric în care termenul este folosit pentru a exprima o stare sufletească atribuită unui muritor. Termenul pentru muritori era ó $\gamma \hat{\eta}$ (lat. ira), în limba homerică. Altfel, tema mîniei era frecventă în eposurile care circulau în epocă. Chiar în Iliada, IX, 520 sqq., bătrînul Fenix povestește legenda lui Meleagru, etolianul care, din cauza unui conflict de familie, a refuzat să participe la războiul împotriva cureților, lăsîndu-și concetățenii din Calidon pradă dezastrului.

${ }^{8}$ Mici variații de grafie etc. apar chiar și în preluările reverențioase, vezi comentariul din DS-I, I, 1. Nu am mai zăbovit asupra altor felurite încercări, unele dintre ele mai mult decît merituoase.
} 
Cînd același traducător român reia, în timp, versiunea realizată inițial, chiar termeni ce au părut cititorilor modele de adecvare în textul homeric au fost schimbați: strigăt este înlocuit cu chiot, ucigătorul cu crîncenul; pocni cu zăngăni (GM). Scrupulozitatea și tot mai buna cunoaștere a originalului determină aceste înlocuiri succesive. Se vede clar dorința niciodată satisfăcută complet a echivalării exacte a termenilor grecești, a pregnanței în română și a încadrării fără smintire în numărul de silabe cerute de vers. Exemplele date fac parte din GM-I, XVI, ultimul (XVI, 115) reuşind să rezolve concomitent atît eufonia, cît şi integritatea hexametrului, în versiunea din 1928, faţă de cea din 1920.

Toate aceste fenomene sînt absolut explicabile în orice traducere de acest fel. Diferențele de cultură și civilizație, accentuate, cum spuneam, de uriașa distanțare în timp a celor două limbi, diferențele de inventar lexical și, nu în ultimul rînd, specificul organizării lexicale a textului homeric, în care rigorile stilului formular generează numai una dintre dificultăți, conduc spre abordările semnalate de noi în aceste pagini.

c) Creativitatea lexicală, justificată oarecum în 1837 și 1876, devine jenantă în versiunile murniene dintre anii 1906-1940. Libertatea de asociere a afixelor productive românești (-ime, -at, -os etc.) și de flexiune nominală şi verbală provoacă aşa-numita „fabricare de cuvinte” („îmbogățirile de limbă”, Eftimiu, 1996, p. 277, 287 ș.a.): sfădălimea, greimea, gîtoase, gîtar, luptaciu; gîfuind, sfetit; a se oști, a se îngloti ș.a. Se creează pulpar și brățar (GM), după pieptar, probabil ${ }^{9}$. Același critic inventariază inadecvările semantice, rezultate din structuri morfosintactice forțate, ahei înarmați în aramă; voinic în vrere, cu efecte pleonastice, cu ambiguități și obscurități inerente.

d) Cuvintele rare își au rostul lor cînd sînt menite să echivaleze un concept rar utilizat în română, precum cronid, harite etc. Din păcate, lipsa de măsură se face simțită și aici, uneori, cf. ostrov pentru 'insulă', mertic pentru 'parte' ș.a.m.d. Riscul utilizării unor asemenea termeni crește prin necunoașterea sensului exact ale acestora: rom. strămurare înseamnă 'țepușăa, eventual ghintuită la capăt, cu care țăranii români își mînau vitele (DLR, s.v.), așa încît folosirea lui pentru noțiunile de 'suliță sau 'lance' este o licență riscantă ${ }^{10}$.

e) $\mathrm{Cu}$ aceasta, am ajuns la sursa cea mai larg răspîndită a selecției lexicului în versiunile românești ale textelor homerice-arbaismele, regionalismele și, la polul opus, neologismele. Primele două subcategorii sînt justificate prin caracterul arhaic și rural al poemelor traduse. Chiar și cei mai înfocați susținători ai ideii de urbanitate, aristocratism, elevație și perenitate a lumii și limbii homerice-este cazul lui G. Murnu și C. Papacostea-își găsesc limanul la izvorul nesecat al lexicului vechi și popular: văzduh pentru cer, slobod pentru liber, crai pentru rege sau prinț ș.a. - la GM; barem, încalte, măre, mîhnire, pricinaș, tînji ș.a. - la CP, ca să nu mai vorbim despre coabe, găzdoaie, haram, indămînă, scaldă, tîndală - la GC. Acestea pot avea justificarea sinonimului poetic în faţa celui curent sau, în unele cazuri, a numărului diferit de silabe, element important în traducerile versificate. Altele însă, precum abraș, aman, deliu, dihai, mehenghiș.a. nu fac decît să întunece textul. I. Caragiani era folclorist la origine, G. Murnu a străbătut și el țara, în căutare de texte neaoșe; ambii cunoșteau ținuturile românești din Munții Pindului pînă în Apuseni, după cum toți ceilalți cunoșteau foarte bine fondul folcloric literar românesc, ca și pe cel scris cronicăresc şi religios. Problema era aceea a decantării în traducere a cuvintelor potrivite cu contextul, cu privire la ambele limbi, precum și a limpezimii și muzicalităţii, în cazul celei primitoare.

În perioada interbelică, limba română uzuală și limba literară ajunseseră la apogeul dezvoltării lor, grație și înfloririi unei literaturi bine conectate la ritmul universal contemporan. Dar și provocările mereu

\footnotetext{
${ }^{9}$ N. I. Herescu afirmă că asemenea cuvinte inventate nu ar reprezenta un mare păcat, dacă ar fi inspirat plămădite, ,adică estetic și în conformitate cu spiritul limbii” (Herescu, 2011, p. 384). Argumentul că și Eminescu folosește obrăzar nu stă în picioare, dincolo de faptul că poetul a creat, într-adevăr, cuvinte noi. În acest caz, termenul exista deja în limbajul apicol românesc. În literatura veche este atestat la I. Budai-Deleanu (v. 5841): „Cesta vinde obrăzare viclene” (J. Byck, 1953; cf. brățări viclene, Gh. Cardaș, 1925).

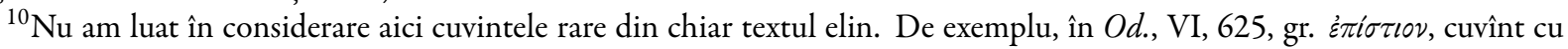
etimologie necunoscută, este un hapax legomenon. GM îl traduce prin șopron, alții - prin adăpost etc. (căci nu rezultă că ar fi o construcție acoperită). Este vorba despre hangarul în care se puneau la adăpost ambarcațiunile trase la mal, cf. Bailly (1950, s.v.).
} 
actuale ale textului homeric acționau în pas cu vremea. Dorința de folosire a metrului original a impus, în consecință, reluarea ciclului căutării „cuvintelor potrivite” în toate straturile și timpurile limbii române, precum și valorificarea personală a feluritelor procedee de creație lexicală. Așa se explică termeni ca zeime, pețitorime, pricinaşi, alergăreața (plută) la C. Papacostea. Asemenea cuvinte formau dactilii, spondeii și troheii necesari succesiunii hexametrului, în varianta românească (cf. Ioana Costa, în CP-O, ed. 2013, p. 7-9).

Eugen Lovinescu își susținea cu tărie concepția privitoare la pierderea, în timp, a vechilor valori estetice (cf. Teoria mutației valorilor), aşa încît, chiar dacă poemele homerice sînt comparabile, în opinia clasicistului român, cu basmele și legendele povestite copiilor, ceea ce ar justifica preluarea vocabularului de rigoare, nu i se pare nepotrivit ca acesta să fie împănat cu termeni ai lumii moderne pentru care a asumat traducerea Odiseei: adunare, bunuri, cadă, capac, cupă, a lustrui, judecător, minge, oraş, a pierde dreptul, planuri, rețele, sală, țară ș.a.

f) În sfirșit, mai ales din rațiuni metrice, cuvinte uzuale, altfel clare și adecvate structurilor morfosintactice respective, sînt folosite în forme aberante, aglutinate-de cele mai multe ori, fără a mai pune la socoteală inversiunile și dislocările sintactice de așteptat într-un text poetic: pieri-necat (GM-Od, IV, 681), Minervatunci (IV, 1064), i-o peşteră (XIII, 144); se arătă potriva zeilor (CP-O, XII, 202), din plute-ntrarmeaz-o (I, 267).

g) Cuvintele imitative, particulele și expresiile fatice, injuriile etc., frecvente într-o structură epică de mari dimensiuni, care mizase la origine pe efectele expunerii orale ale aezilor în faţa unui public coparticipativ, fac obiectul expres al unor fraze din prefața lui Heliade Rădulescu și din notele explicative ale lui C. Aristia (CA-I, p. IV). Oralitatea stilului impunea folosirea unor interjecții și formule de adresare pe care este, practic, imposibil să le găsești în registrele îngrijite ale unei limbi. Poate cîte un $o$, ehei, vai, ah să se încadreze în cerințele stilului înalt. Dar nici măcar aceste clase morfologice, atît de oropsite din punctul de vedere al categoriilor gramaticale, nu sînt vide logicosemantic și nici limitate sintactic. Dimpotrivă, puterea lor de semnificare pragmatică, suprasegmentală, contextuală poate îmbogăți mult încărcătura unui enunț. Așa stînd lucrurile, nu trebuie să ne mire că cititorii avizați ai traducerilor românești au avut reacții diverse, de la elogii la blam, față de expresiile colocviale, triviale chiar, întîlnite în traducerile românești: aoleo (IC); olio (GC); ptiu; (un) huideo (năpraznic); ducă-se naibii (GM).

Utilizate cu măsură și cu har, asemenea elemente „cazone”, să le spunem, ca și inconturnabilele „ziceri imitative” (IHR) pot contribui la realizarea efectelor de culoare, varietate muzicală și dinamism ale textului tradus. Colorat, fluent și elegant sună versurile chiar atunci cînd asemenea vocabule se aglomerează într-o singură pereche de versuri:

$O$, zei, ia uite minunea ce-ajuns-am s-o văd eu cu ochii!

Zău că Troienii cei trufași pe care-i ucis-am odată...

(DS-I, XXI, 54-55)

Uneori, este greu să distingem între necesitate și alegere voluntară, între fidelitate faţă de original și creativitate stilistică adaptată unui tip de sensibilitate din cu totul alt timp și alt loc de receptare, atunci cînd găsim mostre de exprimare vernaculară:

Douăsprezece din iepele mîndre, și bune catîrce,

Tari la dîrvală, nu încă strunite: la ham le-aş cam pune!

Astfel grăi, iar aceia rămaseră paf...

(Ds-Or, IV, 636-638)

Este adevărat că un astfel de discurs îl caracterizează pe Noemon, fiul lui Fronios din Ithaca, unul dintre „obraznicii pețitori” (CP) adunați la curtea lui Odiseu, unde încălcau orice urmă de norme ale ospitalității. Lipsa de urbanitate se manifestă verbal și prin blestemele și injuriile pe care le proferează aproape toți 
pețitorii, veșnic aflați sub puterea vinului băut fără reținere, din rezervele palatului în care se înstăpîniseră, atunci cînd aud că Telemah nu se află la țară, la ferma de porci sau la vreo stînă, cum crezuseră cu toții, ci plecase cu corabia lui Noemon, cerută de la Antinou, spre Pylos, cetatea bătrînului înțelept Nestor. De data aceasta, chiar Antinou, unul dintre prinții ceva mai spălați, se exprimă bolovănos:

\section{...Rău i-a fiş̧i i-a prinde! Ci Zeus să-l bată \\ Şi să-l doboare virtutea nainte să-și ia bărbăția! \\ (DS-Or, IV, 667-668)}

Toate aceste aspecte, notate fugar aici, țin în egală măsură de problematica gramaticii contrastiv-tipologice și de concepția traducătorului cu privire la actul echivalărilor. I. Caragiani era un adversar declarat al inovațiilor lexicale și al neologismelor, dar a cultivat oralitatea stilului, în litera riguroasă a textului. Pentru

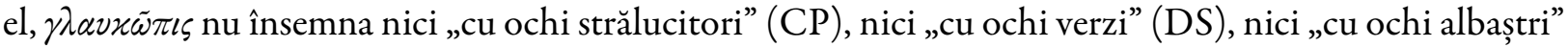
(GM), ci „cu ochi de cucuvea”, în sensul propriu al termenului grecesc ${ }^{11}$. În schimb, pentru G. Murnu nici o inovație nu părut prea riscantă ca să redea spiritul textului și, mai ales, ceea ce el considera că este inventivitate epică: Elena era înciumată, Hermes - pîndăreț; pînă și Aurora, răscunoscută prin „degetele trandafirii”, are în textul murnian „văl șofraniu” (GM-I, XIX, 1) - galben, adică (?). În alte părți, spune totuşi: se ivise zorii trandafirii (GM-Od, V, 301-302). E drept însă că voluptățile lexicogramaticale pe care singur le trăia conduc deseori la rezultate spectaculoase. Vom avea ocazia să vedem că structurile stilistice complexe, de tipul „dormind la porțile visului” (Od., IV, 1080), devin în română Fericire dusă în tărîm

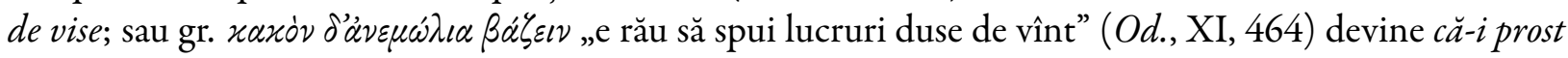
vorbitu-n dodii.

Ca de obicei, calea de mijloc este căutată de Cezar Papacostea, iar cea justă și savuroasă, în același timp, de Dan Slușanschi.

\subsection{Autohtonizarea textelor homerice}

2.3.1. În foarte multe situații dificile de echivalare a textelor homerice în limbile moderne, salvarea a venit din aplicarea principiului localizării, răspîndit în întreaga Europă, mai ales în epoca Romantismului. Principiul a persistat în culturile „mici”, din sud-estul continentului, sporadic și prin alte părți, pînă la sfîrșitul secolului al XX-lea. Pentru traducătorii din literatura Greciei antice, moda s-a suprapus uneia mai vechi - latinizarea, practicată încă de la sfîrșitul Antichității ${ }^{12}$, continuată în tot Evul Mediu și apoi în secolele moderne ${ }^{13}$, cînd traducerile nu s-au mai făcut în latină, ci în limbile naționale, dar anumite arii conceptuale și lexicale au fost redate în continuare în haina latinească, adaptată specificului local. Din acest melanj au rezultat forme particulare ale unor largi categorii lexicale, unele foarte îndepărtate de spiritul Helladei postmiceniene. De altfel, în cîteva cazuri din istoria traducerilor românești, întregul text a fost tratat ca atare, considerîndu-se că atmosfera generală tradițional-locală este în măsură să o sugereze veridic pe cea homerică.

\footnotetext{
${ }^{11}$ Epitetele și metaforele bazate pe sistemul de referință zoologic este curent în eposul grecesc, cf. Hera, soția lui Zeus, cu supranumele $\beta$ ow $\pi \iota \varsigma$ „cu ochi de vacă” (Il., I, 551; III, 144 ș.a.); aceeaşi Hera poate avea „ochi de ciută” etc.; Elena, soția lui

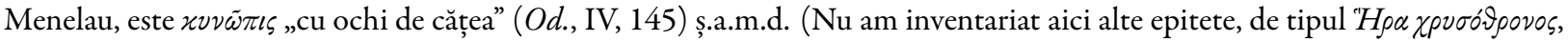
Hera „cu tron de aur” etc.).

${ }^{12}$ Se știe că primul monument de limbă latină literară a fost traducerea realizată de Livius Andronicus din Odiseea (cca 270 a. C.). Versiunile latinești s-au înmulțit în perioada republicană și, mai ales, în cea imperială, astfel încît, la sfîrșitul Antichității, poemele homerice deveniseră nu numai un model literar, ci un bun cultural comun, difuzat printre popoarele lumii în versiunea latinească.

${ }^{13}$ De fapt, tradiția comentariilor în limba latină pe marginea poemelor homerice a fost cea care a menținut utilizarea teonimiei, antroponimiei, toponimiei și a altor grupuri lexicale (terminologia militară, a ierarhiilor civile şi religioase etc.) în limba latină. Prelucrate întîi în Le Roman de Troie (1160) de Benoît de Sainte-Maure, textele homerice au fost traduse în latină în Evul Mediu și Renaștere de umaniștii italieni și francezi, ca Leonardo Bruni, Carlo Marsuppini, Niccolò della Valle, Lorenzo Valla, Angelo Poliziano. Hotărîtoare pentru textul grec și pentru comentariul în limba latină răspîndite în lume au fost edițiile realizate de către Demetrios Chalkokondyles (Firenze, 1488), Aldo Manuzio (Venezia, 1517), Adrien Turnèbe și Henri Estienne (Paris, 1554, respectiv, 1566) ș.a. Cf. D. M. Pippidi, Introducere la GMD-I, p. 32-33.
} 
2.3.2. Și-au teoretizat aceste opțiuni de tehnică traductologică George Murnu, Cezar Papacostea, dar, mai ales, E. Lovinescu, fiecare cu alte categorii de argumente. G. Murnu aduce două motivații în favoarea demersului său traductologic, în general, și a procedeului autohtonizării, în special. Întrucît cultura românească se află printre acelea care nu au o mare epopee națională proprie, traducătorul—care, prin originile sale, aparținea ambelor culturi, greacă și română—credea că poate umple acest gol prin poemele homerice localizate, act realizabil, teoretic vorbind, prin universalitatea lor și prin apartenența la un fond balcanic din care face parte și spiritualitatea românească. Al doilea cuvînt (id est: motiv, argument) formulat de traducătorul care și-a identificat viața cu opera homerică în română este cel puțin la fel de ambițios ca și cel dintîi: românizarea poemelor homerice ar fi un prilej pentru el de a contribui la procesul de îmbogățire și expresivitate a limbii române ${ }^{14}$. Este interesant de adăugat că $G$. Murnu respinge categoric ideea caracterului popular și naiv al epopeilor homerice, dar vîna cea mai groasă a zăcămintelor de limbă și mentalitate românească pe care o exploatează pentru a „îmbogăți” româna, în procesul de transfigurare a eposului oral elin, provine-după cum s-a văzut, de altfel, din exemplele anterioare-tocmai din zonele populare, din cele mai vechi, mai rudimentare și mai ascunse manifestări lingvistice și folclorice ale spiritualităţii românești. Societatea zugrăvită de Homer depășește prin mentalitate, prin nivelul de civilizație și stil de comunicare starea de mijloc a receptorilor din zilele noastre, spune "poetul homerid”, dar în textul (re)produs de el nu ezită să pună în gura personajelor cuvinte și expresii culese special din arii nedesțelenite ale limbii române, cf. supra, 2.2.g). În acelaşi fel procedează și Cezar Papacostea, în comentariile sale și în versiunea proprie a Odiseei. Concepția despre traducerea din clasicii antici și-a exprimat-o în corecta versiune a unor dialoguri platonice și era de așteptat ca traducătorul să susțină stilul înalt ${ }^{15}$. În cazul particular al lui Homer însă, apelul la limba basmelor și legendelor, a proverbelor populare românești, precum și la aceea a cronicarilor și tălmăcitorilor de cazanii îl ajută să-și plămădească forma românească a celor douăsprezece rapsodii traduse din graiul ionic-eolic. Or, asta a însemnat nu numai selecții lexicale impuse de anumite nuanțări din textul original, ci și adaptări onomastice, fatice, de realia și de dogmă religioasă, de mentalități și atmosferă, în cele din urmă.

Cel mai categoric și mai pragmatic în autohtonizarea textului homeric a fost, de departe, E. Lovinescu. Toate conceptele-cheie din ideologia criticului și istoricului literaturii și culturii românești - „mutaţia valorilor”, „modernismul”, „sincronizarea”, „momentul” (determinarea spaţio-temporală), „relativismul percepției valorilor”, „imitația” - se găsesc reinvestite în teoria sa asupra traducerilor. În concepția clasicistului convertit la cercetarea literaturii moderne românești, orice creație artistică este oglinda civilizației care o generează, fiind determinată, la rîndul ei, de sensibilitatea oamenilor locului și timpului respectiv, de condițiile lor materiale, precum și de manifestările spirituale - religie, doctrine economice, politică, filosofie etc. Toate acestea acționează unitar și fixează opera în timp și spațiu:

„Odată cu timpul, partea vie, palpitul operei de artă se scutură, lăsîndu-i mai mult sau mai puțin scheletul, schema ideologică. Firele directe ale intuiției estetice rupându-se peste prăpastia timpului, trebuie să aruncăm, cu multă trudă și erudiție, punțile cunoașterii intelectuale și istorice...”

(Lovinescu, Mutația valorilor estetice, citat din Lovinescu, 2012, p. 31)

\footnotetext{
${ }^{14}$ Consimțind că marii creatori și traducători, ca Dosoftei, Miron Costin, Dimitrie Cantemir, Mihai Eminescu ș.a., chiar au contribuit decisiv la îmbogățirea și definirea specificului limbii române, G. Murnu își exprimă satisfacția de a fi reușit pe deplin în ceea ce și-a propus să realizeze, la rîndul său, în acest sens: ,....am studiat vreme îndelungată izvoarele limbii române, din prezent și din trecut, ca și din toate ținuturile locuite de români, și chiar din cele mai depărtate, unde am găsit un tezaur de vocabule noi și, adăugînd la acesta propria mea putere de creație, am întocmit un vocabular care, judecînd după părerea multora, e poate cel mai variat la care a ajuns verbul românesc... N-am cruțat nici o sforțare... să înfățișez un Homer transfigurat aşa încît să fie al nostru (subl. n., P.G.B.), al poporului nostru, și care, dacă se poate, să fie mai bine actualizat decît în orice altă limbă străină” (G. Murnu, Cuvîntul traducătorului la GM-O, p. 25-26). Încrederea lui Murnu că a reușit să dea limbii române „cel mai variat” vocabular (se înțelege că termenul de comparaţie îl reprezintă textele realizate de către vechii creatori şi traducători români enumerați mai sus, precum și de contemporanii săi) au împărtășit-o, în general, cei care au considerat că versiunea românească murniană este superioară multora dintre cele în alte limbi (cf. A. Pârvulescu, Introducere la GM-O, p. 20; D.M. Pippidi, Introducere la GM-Od, p. 35 ș.a.)

${ }^{15}$ Ideile formulate în Prefața la Platon, Opere, vol. II, Banchetul. Phaidon, București, Casa Școalelor, 1935, au fost reluate în diverse studii publicate în periodice.
} 
Dacă oamenii au putut să creeze noi formule estetice din imitarea celor vechi, acest lucru s-a datorat adaptării la specificul național, în măsura în care vechile modele au reală putere de iradiere în timp și spațiu. Cu privire specială la poemele homerice, E. Lovinescu credea că forța lor estetică poate fi doar reconstituită, prin valorile compensatorii ale gîndirii, simțirii și limbii naționale în care sînt transmutate. Imagini ca "Aurora cu degete de roză” sau „Junona cu ochi de juncă” nu numai că nu au vechiul ecou în sufletul modernilor, dar îi poate chiar jigni, căci sistemul de referințe, socialmente determinat, s-a schimbat mult. În consecință, sufletul întreg sau măcar parțial al ideilor și formelor vechi poate ajunge la sensibilitatea receptorului actual numai dacă un traducător bun găsește echivalențe juste pentru sistemul recent și național. În acest caz, nu este atît de importantă formula unităților logico-sintactice, adică opțiunea pentru traduceri versificate (în metri originali, în versuri rimate) sau pentru proză, pe cît este de importantă esența actualizărilor și autohtonizărilor.

E. Lovinescu și-a adus și el prinosul de laude colegiale la adresa traducerilor lui G. Murnu, în pofida unor mari deosebiri de gîndire și de practică a actului creator și, mai mult, în ciuda faptului că unele critici referitoare la propria-i tălmăcire se formulau adesea luîndu-se drept termen de comparație realizările confratelui deja consacrat în domeniu. Ceea ce conferă valoare versiunilor murniene din Iliada și Odiseea este, în primul rînd, creativitatea verbală, aflată în competiție fertilă cu cea din originalul grecesc. Mai exact, autorul Mutației valorilor estetice considera, pe bună dreptate, că filonul popular al acestei creativități este cel ce reface „atmosfera” din textul originalului, concept frecvent invocat în dezbaterile traductologilor epocii interbelice. Astfel, în dialogul Odiseu - Dolos apar expresii ca "fii liniștit despre asta”; „atîta răspunde-mi” ș.a., care sînt „supte din însăşi plămada originală a limbii române”. Din acest punct de vedere, româna, ca și alte limbi din sud-estul Europei ${ }^{16}$ sînt mai apte să redea ceva din arhaicitatea și oralitatea lumii homerice, în comparație cu limbile cristalizate, „aristocratice”, cum ar fi franceza sau engleza. Eroii homerici nu pot fi puși să vorbească precum marchizii de la curtea regilor francezi. Priam este mai puțin un „roi des rois” și mai degrabă un „moșule dragă”. Româna este o limbă care încă păstrează, destul de bine, o variantă rurală, „,mirosind a lapte și caș”. Așa încît poate că Ion Creangă ar fi fost un bun traducător al Odiseei, dacă ar fi știut greaca veche. Ideea vine în continuarea convingerii lui E. Lovinescu că poemul homeric nu este altceva decît un basm, înrudit, ca fond, cu Harap-Alb și altele asemenea:

\section{„Lestrigonii, Ciclopii, Circe, Scila și Caribda sunt din rasa Spânului, a lui Gerilă, Flămânzilă." (Lovinescu, 2012, p. 336-337)}

Din perspectiva evoluției culturilor, pe care o teoretizase în Istoria civilizației române moderne (I-II, 19241925), ambele specii literare citate aici-epopeea homerică și basmul românesc-sînt emanații artistice populare asumate și definitivate de un creator cunoscut, creații care au același tip de fond ideatic, psihologic și estetic, „proaspăt și naiv”, care nu trece peste nivelul mentalității copiilor.

Întreaga construcție teoretică pe care se întemeiază formulele traductologice ale autohtonizării este condensată în următoarele fraze lovinesciene:

„Pentru moderni, poezia homerică nu poate avea decît valoare noțională; întregul element sugestiv, intregul zăcămînt emoțional de reziduuri ancestrale, pe care-l are orice limbă și pe care trebuie să-l fi avut cu deosebire o limbă proaspătă ca limba elenă, cu imagini și metafore vii încă, legate prin credințe multiple in senzație, întreaga această sevă bogată, colorată, care circula în poezia homerică a dispărut pentru totdeauna, pentru necunoscător, ca și pentru cel mai adînc cunoscător al limbii și civilizației elenice...

...întrucît valoarea de sugestie poetică a Iliadei este pierdută pentru totdeauna, ... (ea) poate fi recreată, cu mijloace proprii și pe răspundere proprie, de traducătorii moderni."

(Lovinescu, 2012, p. 334-337)

\footnotetext{
${ }^{16}$ Despre situația traducerilor în această parte a Europei, unde s-a păstrat pînă de curînd tradiția barzilor populari, colportori/creatori ai unor eposuri de tip homeric, cf. Bârlea (2015a).
} 
2.3.3. Înainte de a analiza sistematic în ce măsură au procedat la autohtonizări traducătorii moderni români ${ }^{17}$, se cuvine să precizăm că termenul în discuție acoperă două niveluri de manifestare:

1) Nivelul de suprafață, promovat numai de unii traducători, constă în localizarea sistemului de credințe, mentalităţi, atitudini, pe de o parte, și a referințelor la organizarea socială și materială, pe de altă parte;

2) Nivelul profund, difuz și universal constă în utilizarea pe scară largă a lexicului uzual, al construcțiilor morfosintactice și stilistic-pragmatice din limba națională vie, populară, arhaică.

\subsubsection{Localizarea valorilor spirituale și materiale}

Cele mai vizibile—și mai șocante, pentru cititorii avizaţi ai textelor homerice—au fost adaptările operate în sfera credinței religioase, a mitologiei, superstițiilor, a întregului sistem de referințe din zona relației omului cu supranaturalul, dar și cu natura și cu universul însuși. Problema a fost discutată încă de la începuturile apariției unor traduceri semnificative din Homer în română, atitudinea cea mai cunoscută fiind aceea exprimată în cuvîntul de însoțire scris de I. Heliade Rădulescu la Iliada, pe care i-o scotea lui C. D. Aristia, în 1837. Ar fi ușor să folosești nume și epitete din credința ta: Atotputernicul Dumnezeu, Dumnezeitul, Îndelungrăbdătorul, Multmilostivul ș.a. Dar dumnezeii, eroii, obiceiurile și, implicit, epitetele acestora se schimbă peste veacuri și nu avem voie să folosim denumiri creștine pentru zei păgîni, care trebuie numiți, cumva, în spiritul vremii (Denalttunătorul, Noriîntărîtorul, Ochiosul), aşa cum procedează C. D. Aristia (CA-I, p. IX). De fapt, în CA găsim un amestec de nume grecești și latinești Apolon, Ulis, Agamemnon, Nestor; Joe, Zea Juno, Zea Minerva, pentru care a creat epitete românești prin calchiere (argint-arcatulZeu; braţalba Juno), prin traducere totală (năprasnicul Polifem) sau prin împrumut direct (Phebu, Glaucopa).

Celălalt deschizător de drumuri din secolul al XIX-lea, I. Caragiani, iş̦i concentrează ideile despre traducere în scurtul cuvînt Către cetitori din ediția în proză a Odiseei, 1876. Considerînd că textele homerice reprezintă „limba copilăriei poporului grecesc”, cărturarul aromân decide că limba populară și limba cărților bisericești le pot exprima cel mai potrivit în română, cu condiția să fie evitate formele rare, greu de înțeles. $\mathrm{Cu}$ atît mai mult, nu agrea intervențiile și invențiile personale: „nici n-am stricat, nici n-am dres limba”, iar de cuvintele neauzite în gura poporului s-a ferit cît a putut ${ }^{18}$.

În privința redării universului credințelor religioase din textele homerice, lucrurile stau ceva mai încurcat. Zeii, eroii etc. poartă numele lor grecesc, original, adaptate fonomorfologic, evident, la sistemul limbii române: Zeus, Athena, Odiseu, cu obişnuitele epitete, destul de fidel urmate: Cronide, Olimpicul, respectiv cea cu ochi de cucuvea, divinul, multîncercatul, multiscusitul, iar în notele de subsol, foarte bogate, a dat și echivalentele latinești-tribut plătit modei europene, încă vie pe atunci, și, cu siguranță, didacticismului declarat al unor astfel de traduceri. În fapt, cînd este vorba despre epitete din sfera religioasă, Caragiani traduce adj. dıós prin „dumnezeiesc”, ceea ce înseamnă o primă mare concesie făcută autohtonismului propriu-zis. Doar editorul din 2011, Ion Acsan, găsește de cuviință să intervină pe textul original, traducînd termenul grecesc prin „divin”, polisemantic, sau prin „zeiesc”, mai direcţionat păgîn. Considerate anacronisme, mai multe asemenea vocabule sînt schimbate: biserică prin templu etc. Rămîn neschimbate: O, Doamne! sfintul oraş, înlocuit, uneori, totuși, cu sacru; prorocire / prorocit / proroci; fruntași și sfetnici ș.a. Dacă adăugăm la opțiunile personale, necorijate de editorii moderni, și nivelul profund al graiului popular, la care întemeietorul catedrei de specialitate de la universitatea ieșeană a aderat deschis dintru început, putem spune că versiunea IC reprezintă un model de autohtonizare bine temperată.

Dintre neaoşismele utilizate de harnicul culegător de folclor și de filologul Caragiani, în Odiseea sa, menționăm:

\section{- daurita Afrodită; Ostrovul Eolin, în palatele Crivățului (din Thracia); Baba Hîrca;}

\footnotetext{
${ }^{17}$ Insistăm asupra faptului că acest fenomen nu a caracterizat numai traducerile în română, și nu numai pe cele din Balcani (versiuni în sîrbă, croată, bulgară, albaneză, macedoneană slavă etc.), ci și pe cele ungurești, slave răsăritene, ba chiar și pe acelea din apusul și nordul Europei (franceze, engleze, italiene, suedeze, norvegiene ș.a.), cu deosebirea că, în cazul acestora din urmă, procedeul „împămîntenirii”, cum îl numea englezul George Chapman, un adevărat fondator al traductologiei și homerologiei anglo-saxone, a demarat pe la sfîrșitul secolului al XVI-lea și a încetat, în principiu, odată cu sfîrșitul Romantismului.

${ }^{18}$ Traducătorul, filologul și lingvistul ieșean I. Caragiani declară că și-a expus mai pe larg ideile în volumul tradus din Iliada şi aflat „sub presă” în 1876 (Caragiani, Către cetitori, în IC-O, p. 9). Din păcate, acel volum nu a mai apărut vreodată.
} 
- nădăjduiesc să săvîrșești; Haide, femeie! Mamă-ta;

- straie, merinde, nuri; din fitil.

Proverbe și zicători adaptate:

- tot ce-i drept este bun; pentru oamenii cei răi și chezăşiile sînt rele etc.

După aceste ezitări și evidente căutări ale unui echilibru între limba literară și cea popular-arhaică, între respectarea spiritului elin și localizarea românească a unor realități și aspirații umane, ne-am fi așteptat ca secolul modernismului să aducă orientarea decisă spre cea dintiii manieră de lucru. În cultura românească, cel puțin, nu a fost deloc aşa. Epoca marilor realizări în domeniul traducerilor din textele homerice a fost și epoca transformării acestor „,anacronisme” în principiu de abordare a textului homeric. Formele latinizate ale numelor de zei, eroi și alte personaje, ale unor cetăţi, ape, munți au complicat și mai mult autohtonizarea propriu-zisă, manifestată sub toate aspectele. La G. Murnu, cel mai prolific şi mai dedicat românizării textelor homerice, apar atît de multe asemenea adaptări, exersate în numeroasele sale fragmente, ediții și reluări integrale, încît aproape că nici nu ar mai avea rost trimiterile-paginile de mai sus conţin deja exemple grăitoare, în acest sens. Joe este preluat din CA, dar Ulise este preluat direct din tradiția umanistă occidentală, ca și Neptun, Vulcan, Minerva. Epitetul Cronides devine Saturnianul, căci, după cum Zeus este fiul lui Cronos, tot așa și corespondentul său latin, Juppiter, era fiul lui Saturn (GM-Od, I, 68 ș.a.). Eriniile sînt Furii, iar Harpiile sînt Vîntoasele ${ }^{19}$, deci aici acționează traducerea directă. Pe de altă parte, același Joe devine Dumnezeu, cel puțin în formulele de consecrație: Păzească Dumnezeu (GM-Od, I, 543); Dumnezeu m-ar bate (GM-Od, II, 188) ș.a. Termenul Domnul este folosit în sens teologic, dar și în sens laic-administrativ (să fie domn în țară, GM-Od, I, 541; e domn peste popor, I, 562); cf. și Domnița Nausica (GM-Od, VI, 19).

În aceeaşi sferă semantică, templul devine biserică, iar tot ce e sacru devine sfint-ca și în CA sau în IC. Reacțiile la astfel de adaptări au fost pe măsură. Ca și Heliade Rădulescu, altădată, V. Eftimiu considera asemenea forme o profanare a dogmei receptorilor. Biserica, Sfintul și Domnul sînt ale noastre, ale creștinilor; ale lui Homer erau Templul, Divinul, Zeus (Eftimiu, 1996, p. 251). Cît despre traduceri de epitete/nume formate prin antonomază, la cele de mai sus se pot adăuga altele, nenumărate. Ares, zeul războiului, este Războilă, iar Vînturile de Miazănoapte devin Borilă. În felul acesta, zice multcitatul V. Eftimiu, din Zeus s-ar fi putut face „Trăznilă”, și fiecare erou homeric ar putea fi echivalat cu un personaj din basmele lui P. Ispirescu.

Procedeul nu se încadrează, tehnic vorbind, nici la traducere, nici la calc lingvistic, fiind un soi de localizare forțată a conceptelor denumite astfel. Întregul evantai de asemenea procedee a fost pe larg utilizat în traducerile din perioada interbelică.

La acest nivel, al adresărilor și diverselor formule de consecrație, G. Coșbuc reface ambianța credincioșiei rustice românești în toată libertatea, prin expresii de tipul Domnul știe cum!, Ferească Dumnezeu!, Ferească sfintul!, l-au stins din lume sfinții, frați de cruce ș.a.

Epitetele sau titlurile ierarhice divine și umane, supranumele folosite ca nume, prin metonimie, se încadrează în acelaşi curent al localizărilor. În versurile lui G. Murnu, Agamemnon, regele regilor, precum şi Priam, regele Troiei, sînt crai, înțeleptul Nestor este Moș Nestor, Polipoide este Luptaciul, iar Stenelos este numit de Diomed bădie. În altă parte, Agamemnon, ca și Zeus, de altfel, sînt împăraţi, iar sfatul zeilor este numit divan (GM-I, XI, 5).

În același fel procedează și C. Papacostea, care caută echivalențele pentru titulaturi, ierarhii, funcții social-politice și religioase în cronicile românești și în folclorul literar naţional: Dumnezeu, zîna zînelor; chelăriță, paharnic, voievozi, crai, stăpîni ș.a.m.d. De fapt, în atari situații, chiar și traducătorii din limbile occidentale, demult rafinate în epopei și poeme proprii, recurg la o anumită manieră de autohtonizare, la nivelul culturii și civilizației lor. În discursul lui Alcinou către mai-marii soborului său, în $O d$., VIII, 97, găsim aceste formule:

\footnotetext{
${ }^{19}$ Textual, harpyai înseamnă „răpitoare”.
} 


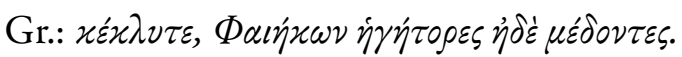

Rom.: Ian ascultați, voievozi și stäpinni ai noroadelor voastre (CP)

Fr.: Doges et conseillers... (VB)

Observăm că și Victor Bérard, foarte apreciat de cititori în epocă, dar considerat de filologii clasici prea îndepărtat faţă de original ${ }^{20}$, echivalează funcțiile fie prin adaptare spațio-temporală, fie prin generalizare. În versiunile românești, localizările sînt aproape unanim cultivate, chiar și la traducătorii care s-au declarat categoric împotriva schimbărilor onomastice și de orice alt tip:

\author{
Ascultaţi, voi fruntași și sfetnici... (IC) \\ Luați aminte, fruntași și sfetnici (EL) \\ Luați aminte, voi fruntași și sfetnici (GM) \\ Mă ascultați, voi, Feaci, căpetenii și sfetnici de seamă (DS)
}

Bine încadrate în text și naturalizate, oarecum, sînt echivalările lui C. Papacostea. Pentru o formulă de adresare precum gr. $\gamma \alpha i \delta \mu$ 'O $\delta v \sigma \sigma \varepsilon \tilde{v}$, cercetătorii avizați compară versiunile română și franceză:

\title{
Luminate impărate (CP) \\ Noble Ulysse (VB)
}

Calipso, numită de aed „zeița zeițelor”, este transformată în personaj de basm la CP, spre deosebire de superlativul folosit în franceză de V. Bérard, este adevărat-unul de tip popular, chiar și în limba lui Molière:

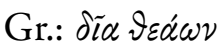

$$
\begin{aligned}
& \text { Rom.: zîna zînelor (CP) } \\
& \text { Fr.: cette toute divine (VB) }
\end{aligned}
$$

Eos „cea cu degetele trandafirii”, numită Aurora în versiunile latinizante-franceze, românești ș.a.—, devine Zîna Zorilor (CP). Regele grec, precum Alkinoos sau Menelaos, este $\beta a \sigma l \lambda \varepsilon v$ s, care devine crai în română (CP ș.a.). Eumelos, cumnatul lui Odiseu și tatăl Iftimiei, este Evmel Împărat (CP), ca „Roșu Împărat” sau „Negru Împărat” din basmele românești. Arete, regina, soția regelui feacilor, $\beta \alpha \sigma i \lambda \varepsilon i \alpha$ în greaca homerică, este crăiasă, iar fiica regilor feaci, Nausicaa, este domniță (CP). Divinitățile care întruchipează vînturile sînt, la rîndul lor, Boreas, dar și Crivățul, Austrul etc., la același CP.

În manieră similară se procedează și cu alte personaje de același rang. Hera i se adresează astfel soțului ei, Zeus, în Od., I, 45:

$$
\begin{aligned}
& \text { Gr.: "Y } \pi \alpha \tau \varepsilon \varkappa \rho \varepsilon 10 ́ \nu \tau \omega \nu \\
& \text { Rom.: Inălțate Impărate (CP) } \\
& \text { Fr.: Suprême Majesté (VB) }
\end{aligned}
$$

În timp ce echivalările din limbile moderne ale „culturilor mari” sînt relativ corecte, dar „fără culoare”, cele românești li se par unor filologi români frumoase, naturale, inspirate, fără să piardă mult din exactitate (Herescu, 2011, p. 145-146).

Apogeul acestei mode în traducerea textelor homerice l-au constituit versiunile GC și EL, fiecare în felul ei, dată fiind nu atît distanța în timp, cît particularitățile privind formula poezie/proză, originalul de la care s-a pornit și concepția despre limba literară. Așa cum am arătat, în traducerea EL-O, Zeus este cînd Juppiter, cînd Dumnezeu, întreaga arie semantică a credințelor și superstițiilor fiind tratată în aceeași

\footnotetext{
${ }^{20}$ Însăși ediția din 1924-1925, încercare de „reconstruire a unei Odyssei primare”, este considerată astăzi nerecomandabilă, ca fiind rodul unei fantezii debordante, cf. Ds-Or, p. 403.
} 
manieră, de la Doamne (p. 16), Slăvite Doamne (p. 33); mărite Doamne (p. 39/41), Dumnezeu (p. 39), vai, Doamne (p. 45), Ferească Dumnezeu (p. 36, 36, 40), Cel de sus (p. 53), pînă la zîne (p. 45), zînă dragă (p. 57), zîna (p. 58), moșule dragă, maică, mătușăa, feții mei (p. 37).

Nestrămutat în părerea că poemele homerice reprezintă lecturi instructive pentru copii și adolescenți, ca și basmele naționale ${ }^{21}$, le folosește din plin pe acestea din urmă ca sursă lexicală, deplîngînd din nou, cum o făcuse în eseul Mutația valorilor estetice și în alte studii, paradoxala incapacitate a limbilor evoluate occidentale de a reda asemenea scrieri, „naive și primitive” ${ }^{22}$. Teoria lui E. Lovinescu este mai argumentată și mai seducătoare decît realizarea practică în proză a Odiseei românești. Traducătorul a localizat, a adaptat la ceea ce considera el că reprezintă specificul sensibilităţii naționale a epocii, dar nu a creat „sugestia” despre care a vorbit atît de mult. In schimb, a reușit să facă acest lucru poetul G. Coșbuc, care a urmat o versiune intermediară, germană, relativ „rece” și, în orice caz, științifică (inclusiv prin faptul că era încărcată de note explicative), care l-a ajutat să înțeleagă foarte bine despre ce este vorba în originalul grecesc, inaccesibil lui prin lectură directă. Despre versiunea EL s-a spus că este „o operă literară, nu filologică” (Traian Costa, „Note asupra ediției”, în EL-Or 5 , p. LV), iar despre versiunea GC s-a afirmat că reprezintă un model de „fidelitate și frumusețe”, un „splendid” text nou, în marginea epopeii homerice (GC-O). Și asta, pentru că, alături de substituirea teonimelor (Zeus/Dumnezeu) și adaptarea fonomorfologică a celorlalte referințe onomastice (Ermia, pentru Hermes etc.), G. Coșbuc a preluat de la modelul românesc I. Caragiani toate celelalte arii lexicale, lărgindu-le și ducînd pînă la extrem pecetea rustică valahă imprimată pe textul homeric:

- formule de adresare: bade, bunică dragă etc.

- termeni specifici de realia autohtone: cergă, opinci, (lînă) țigae.

- expresii ce reflectă un stil de viață rural, cum au remarcat exegeții versiunii: Telemah doarme în cerdăcel și suie armele în culă; lui Odiseu i se așterne un țol de lînă și o velință de in; pe masă se întinde un ștergar curat; Nausicaa spală ii și lăicere; slujnicele cîrpesc straie; Nestor șade pe o laviţă cioplită etc. (Cazimir, în GC-O, p. XV-XVII).

- epitete, atitudini și acțiuni cu totul specifice atributelor zeilor greci sînt redate prin frazeologisme idiomatice românești: Penelopa este „burduf de vedenii”; Menelau „are gînduri coapte”; însoțitorii lui Odiseu sînt „gata de măciucă”23.

\subsubsection{Lexic uzual și construcții gramatical-stilistice cu valoare locală}

$\mathrm{Cu}$ aceasta, ne-am întors însă la analiza vocabularului general al versiunilor românești.

a) Nimic din ceea ce poate configura sistemul variantelor populare, dacă se poate vorbi despre un asemenea sistem, nu a rămas nevalorificat în traducerile din Homer realizate în cadrele limbii române. Enumerăm aici numai cîteva subcategorii lexico-gramaticale:

- Termeni populari, arhaici, regionali, construiți după mecanismele de compunere, derivare și conversiune de tip popular: coabe, codrulet, fărtați, fiștecare, găzdoaie, îndămînă, prăpăd, tîndală.

- Locuțiuni și expresii neaoșe: a avea saț, a pune la cale, a da gata, a lua la vale, a face ispravă; legați-l cobză, bată-l vina, lovit de streche, intr-o ureche.

- Construcții metaforice din inventarul generat de mentalităţile românești de tip rural: a prinde în iţe, a merge cu vorba, a ieși cu plinul, a strînge la pungă („a înșela”).

\footnotetext{
${ }^{21}$ În Prefață la ed. I, 1935, E. Lovinescu mărturisește că a preluat această convingere din vechea pedagogie germană (EL-O, p. 9).

${ }^{22}$ „Traducerile franceze făcute de savanți și chiar de mari poeți [vizați erau Victor Bérard, respectiv Leconte de Lisle] nu dau nici pe departe savoarea textului antic: limba franceză e precisă, logică, saturată de eleganță și modernitate, așa că instrumentul ei deformează caracterul rural al lumii homerice și transformă conacul din Itaca în curtea de la Versailles... Cu totul alte posibilități oferă limba română, de esență rustică și patriarhală, în plină formație și deci cu posibilități de creație verbală și de mlădiere. $\mathrm{Cu}$ un astfel de instrument se putea încerca desțepenirea flexibilității homerice din stilistica franceză, solemnă și curtenitoare, pentru a o reda într-o ciobănească sfătoasă și persuasivă, melifluă și candidă” (EL-O, Prefață, p. 10).

${ }^{23}$ Inventarul bogat selectat de Ștefan Cazimir, în Prefață la GC-O, este pus în legătură cu influența pe care o va fi exercitat I. Caragiani asupra poetului român (p. VII-VIII).
} 
Practic, la GC, ca și la EL și, parțial, în CP, zeii Olimpului vorbesc țărănește, ca personajele din Povestea lui Harap-Alb, ceea ce conferă textului farmec, vioiciune, culoare locală și, cum s-a observat, „autenticitate” românească și rurală, evident (GC-O, p. XIV). Dialogul Poseidon-Hefaistos, în legătură cu slobozirea lui Ares $^{24}$, sună astfel:

- Dă-i drumul! Că mă fac chezaşul, frate,
Că totu-ți va plăti, cît ceri și cît
E datina-ntre zei și-i cu dreptate!

- Ab! De-asta nici nu-ți mai răci cuvîntul.

(GC-O, VIII, 355-358)

Athena îl sprijină pe Telemah, dar nu-i garantează izbînda finală, așa că, în caz că acesta ar afla că Odiseu/Ulise e mort, îl sfătuiește:

...găsește-i mă-tei omul și-o mărită! (GC-O, I, 50)

Desigur, asemenea asprimi în exprimare au fost preluate de Coșbuc nu atît din versiunea germană a textului homeric, cît din modelul românesc oferit de traducerea lui Caragiani. Editorii au remarcat aceste filiaţii (GC-O, I, p. XVII), iar ceea ce observăm noi, privind comparativ textele, este o sporire a îndrăznelilor expresive preluate din sfera cotidianului rural la Coșbuc. Cearta dintre bătrînul cerșetor Arnaios/Iros, un obișnuit pe la ușile palatului din Ithaca, și Odiseu, deghizat în cerșetorul străin, care tocmai sosise de aiurea și îndrăznise să i se alăture pe prag, luîndu-i astfel din spațiul unde „localnicul” fusese tolerat de pețitori, seamănă foarte bine cu cearta dintre personajele lui Creangă—din Harap-Alb sau chiar din episodul Mogorogea al Amintirilor din copilărie:

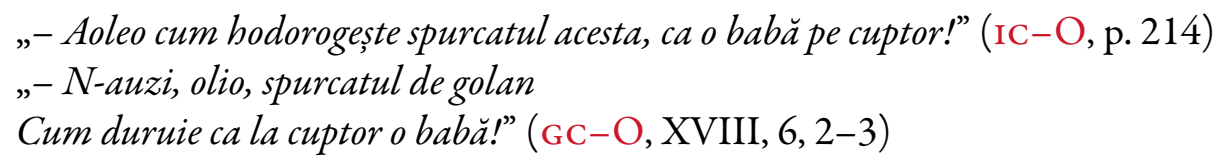

În EL, dialogurile sună oarecum la fel. Din schimbul de replici Athena-Nestor-Telemah, analizat parțial de noi, putem extrage fraze ca acestea:

Nestor...:

- „Ferească Dumnezeu să mergeți la corabia voastră, ca și cum ați fi tras la un om sărac, ce niar avea la casa lui nici așternut, nici scoarțe pe care să se odihnească oaspeții...”

Minerva...:

- „Că bine zici, moşule dragă, și se cuvine ca Telemac să te asculte, că aşa e cu cale...” (EL-O, p. 36).

\footnotetext{
${ }^{24}$ Grecii proiectau asupra zeilor, cum se știe, nu numai cele mai înalte aspirații omenești, ci și păcatele lor obişnuite. Strălucitoarea Afrodita, măritată de tatăl ei cu harnicul, talentatul, dar diformul Hefaistos, cedează avansurilor chipeșului Ares, primindu-l adesea în chiar patul conjugal. Soarele-Atotvăzătorul-îl înștiințează pe soțul încornorat, care le pregătește o capcană din lanțuri invizibile. Rușinat și îndurerat, Hefaistos cheamă, totuşi, zeii să-i vadă pe cei doi adulterini, așa cum se aflau. Evident, nu-și mai alege cuvintele, spre amuzamentul celor de față. În ciuda posturii sale deloc onorante, Ares rostește un scurt discurs care se încadrează total în codul onoarei, iar Poseidon, ca mai mare între cei prezenți, propune o rezolvare a crizei prin apel la principiul răscumpărării materiale a daunelor morale, pentru care însuşi se oferă garant, cf. Od., VIII, $266-366$. Versurile citate mai sus, în versiunea GC, redau doar replicile sfătos-populare dinspre finalul episodului, nu toată descătușarea verbală, exprimată prin „cuvintele mîniei”.
} 
Prin asemenea întorsături de cuvinte, întregul cadru de viață al poemului homeric se schimbă pe nesimțite, integrîndu-se în ambianța tradițională a satului românesc. De la detalii ale vieții materiale și socialeconomice etc., se ajunge, prin valorificarea virtuților pragmatico-stilistice ale limbii române, la o nouă sugestie a modului de a gîndi și de a simți. Fără să fi cunoscut teoriile lui E. Lovinescu despre mutația valorilor estetice, G. Coșbuc a creat în mod intuitiv, prin forța geniului său poetic, nuanțe noi pentru exprimarea mentalităților general-umane, desigur, nuanțe care actualizează și localizează întreaga atmosferă, reînviind o lume de mult apusă și făcînd-o ușor de înțeles pentru cititorul modern, în varianta culturală determinată spiritual și material de noile condiții. Gradul maxim al autohtonizării înseamnă, așadar, că personajele vorbesc, gîndesc și acționează în spiritul național al versiunii realizate într-o cultură nouă. Atena îi spune Nausicăi că „soacra mare așteaptă dar”; Menelau nu vrea „să-i plece un oaspete aşa, flămînd din casă”; Evrimah se teme să n-ajungă „de rîsul lumii-ntre femei”; Telemah n-ar vrea să fie socotit „slab de minte”; Penelopa crede că rătăcirea Elenei este de înțeles, „căci slabe-s, Doamne, mințile femeii!” ș.a.m.d.

b) Terminologia diverselor domenii a constituit o permanentă provocare pentru competențele traducătorilor, atît în decodificarea semnificațiilor din limba-bază, cît și în găsirea echilibrului din limba-țintă.

În analiza tabloului de natură din $O d ., \mathrm{V}, 63-74$ - peisajul din preajma peșterii nimfei Calypso-, am identificat cel puțin șase (!) cîmpuri semantice în numai unsprezece versuri. Constituie provocări, în primul rînd, dendronimele, fitonimele și ornitonimele. La acestea, se adaugă două nume de biotopuri - codrul și crîngul, precum și mediul acvatic (marin și lacustru, natural și amenajat, în alternanțe), greu de identificat exact, căci şi termenii, și descrierea sînt interpretabile. Am arătat, la locul cuvenit, cum, chiar în interiorul fiecărei limbi, apar confuzii generate diatopic, diacronic și diastratic, confuzii care se accentuează în perspectiva contrastiv-tipologică a limbilor (cf. Bârlea, 2015c). Seriile sinonimice și cvasisinonimice se conturează destul de neclar în cadrele cîmpului semantic mai larg: cucuvea, bufniţă, bubă; toporaşi, viorele, violete; ulmi, arini, anini; pădure, codru, crîng; luminiş, pajiște, măgură; izvor, fintînă, cişmea; malul mării etc.

La aceste serii, opțiunea pentru forma veche și populară este mai ușoară, deoarece nu există o variantă literară unanim acceptată care să se afle între termenul popular uzual și cel științific (latinesc, eventual) nici în română și nici în alte limbi moderne.

Dar lexicul de specialitate cuprinde sute de termeni pentru domenii reprezentative ale eposului homeric. Numele de arme, în Iliada și Odiseea, au constituit grele probe de profesionalism pentru traducători, cf. supra, 2.2.b). Cînd termenul este relativ vechi și uzual în ambele limbi, lucrurile par mai simple: arc, săgeată, lance, suliță, sabie, scut etc. De fapt, chiar și în situația-ideală, dar mult mai puțin frecventă decît am fi dispuși să o credem ${ }^{25}$-a identității totale a noțiunii în cele două limbi, traducerea se complică prin integrarea termenului în sintagmele specifice: în română, luptătorul „se încinge cu sabia” la brîu, pe cînd în greaca homerică „își atîrna sabia la spate” (cu o legătură de piele, frumos lucrată), cf. DS-I, p. 401, unde este dat și exemplul cailor—care se „înjugau” la căruță (ca și catîrii, boii etc.), pentru că grecii antici nu cunoșteau hamurile rezistente din piele.

Deseori, opțiunea pentru o anumită formulă este hotărîtă de nevoile metrice ale versului, nu de justețea semantică: sabie are trei silabe, cu valoare dactilică, în timp ce paloş sau spadă - numai două, pretabile la un final de vers sau la o secvență trohaică de interior.

Între aceste criterii de selecție se strecoară, perfid, și demonul împămîntenirii termenului: custură pentru „cuțit”, pală pentru „sabie”, pieptar pentru „platoșă”, culă pentru „turn întărit”, liman pentru „ț̆ărmul de refugiu”, ostrov pentru „insulă” etc. Uneori, autohtonizarea cu orice preț, dublată și de un estetism suigeneris, conduce la greșeli flagrante de echivalare. Între suliță și lance, alegerea poate ține sema de structura silabică sau/și de nuanța semantică pe care ar exprima-o, eventual, fiecare dintre cei doi termeni. În GM,

\footnotetext{
${ }^{25}$ Este suficient să amintim că armele cu tăiș lung, numite generic sabie, sînt foarte diferite ca tehnică de fabricație și ca utilizare în epoci și în spații diferite ale civilizației lumii, de unde seria paloş, iatagan, floretă, spadă ș.a. Din această perspectivă, nu știm niciodată dacă paloș, pală, sabie reprezintă sinonime perfecte sau doar cvasisinonime, respectiv nume pentru noțiuni înrudite, dar nu identice.
} 
găsim însă un al treilea termen: strămurare. Dificil, ca alcătuire fonomorfologică, pentru încadrarea în tipurile de vers pretabile la ritmul epopeic, dificil și ca semantism, căci reprezintă un termen arhaic aflat la marginea cercurilor convenționale care configurează masa vocabularului, mai precis în aria extremă a cuvintelor „ieșite din uz”, vocabula este și inadecvat folosită în context. „Strămurarea” era varga sau prăjina ascuțită la un capăt, cu care erau mînate din urmă cirezile de vite în vechime, în satul romînesc (cf. DLR, s.v.). Chiar în situația, rarisimă, a ghintuirii la capătul ascuțit, nu există atestări ale folosirii acesteia ca $\operatorname{armă}^{26}$, și logic nu este de crezut acest lucru nici dacă am lua în considerare ridicarea spontană a norodului la luptă cu ce avea la îndemînă: topoare, furci, coase, bîte.

În legătură cu aceste din urmă ,arme”, este de precizat că primitivismul unora dintre ele justifică teoria fondului ancestral comun al civilizațiilor cu istorie lungă în Balcani-elină și română, în cazul de față. Reteveiul, ghioaga, măciuca făceau parte din arsenalul aheilor și troienilor, dar și al românilor, deopotrivă, așa încît echivalarea lingvistică a textelor respective s-a impus ceva mai simplu și mai firesc. Alteori, asemenea oportunități trec neobservate de cititori, ba chiar și de traducători, căci termenul pare prea de uz comun. Am menționat (Bârlea, 2015c, Sec. 3.1), în analiza scenei morții lui Diores (Il., IV, 517-526), că selecția homerică $\lambda \tilde{\alpha} \alpha \varsigma$, din seria seria sinonomică $\pi \varepsilon \dot{\tau} \tau \rho \alpha$ etc., nu este întîmplătoare. Piatra care a zdrobit glezna și tendoanele eroului epeu avea o anumită configurație: suficient de mică, încît să poată fi ținută în mînă și aruncată la distanță, suficient de mare și de colțuroasă, încît să producă dezastre. În românește, termenul pietroi se încadrează relativ bine în context, dar traducătorii români îi adaugă epitetele homerice: sgrebulos, zgrebînțos, ascuțit, colțuros. Aceste compliniri semantice îi luminează rostul, mai ales epitetul ornant, care exprimă, de fapt, într-un singur cuvînt, preambulul litaniei concentrate (în stil lapidar, ca să facem și noi o figura etymologica!), la moartea celui lovit: nemilostivul pietroi.

Alte arii lexicale care dau personalitate poemelor homerice, cum ar fi terminologia oficierii sacrificiilor, terminologia culinară, a recipientelor etc., produc aceleași tipuri de probleme, cu aceleași soluții diversificate-traducere, calchiere, perifrază —și cu aceleași tendințe centrifuge spre localizare: limbi fripte, merinde, ceaun etc. Modalizarea intervine în secvențele lingvistice ale săvîrşirii actului în sine cu acestea: ceaunul „se ridică”; merindele „se îmbucă” etc. Uneori, traducerea verbum a verbo lasă în obscuritate textul: frigări în cinci crăci (CA-I, p. LXIII, n. 2). Cum era de așteptat, mai ales în primele versiuni se face apel și la împrumut. La 1837, Costache Aristia simte nevoie să justifice termenul românesc literar de origine latină grații prin faptul că în fondul popular românesc nu a găsit echivalentul pentru gr. harites.

Mai importante sînt situațiile în care a împrumutat direct din textul original. În versul din rapsodia I, 14, La navele ale repezi Aheilor veni, traducătorul adaugă o notă de final de capitol, în care explică de ce a preferat să încetățenească în română cuvîntul navă, după gr. vaṽ s, -ós. „Zicerile” navigație și naufragiu fuseseră primite mai dinainte în limba noastră, atestă autorul notei (probabil prin intermediar străin francez, italian etc.), dar cuvîntul-bază pe care s-au construit acestea în limbile donatoare - nu. Ca să scape poezia sau măcar versurile sale de zicerea corabie „de două ori mai lungă și de zece ori mai neroadă”, i s-a părut că poate folosi navă, pentru ca navigație să devină analizabil în română. Cineva trebuia „s-o ia de la cap”, adaugă filologul revoluționar, „să nu lase genealogia acestor ziceri fără [explicație]” (CA-I, p. 32, n. 4$)^{27}$.

Așadar, autohtonizarea a însemnat, mai întîi, apelul la termeni din fondul popular tradițional al limbii versiunilor moderne, pentru obiecte, ființe, procese, fenomene considerate rurale și arhaice în chiar structura lumii homerice. Apoi, a fost adaptat sistemul de credințe, datini, ritualuri la specificul național, prin încreștinarea divinităţilor păgîne, și încă în versiunea naţională a „credinței străbune”, id est: creștinism altoit pe reminiscențe precreștine, într-un sincretism cu note de originalitate unanim acceptate pînă în ziua

\footnotetext{
${ }^{26}$ Nici acest detaliu nu i-a scăpat acerbului critic V. Eftimiu, la fel de bun cunoscător al graiului românesc, din Pind pînă în Apuseni, și cel puțin le fel de bun poet (Eftimiu, 1996, p. 250-251).

${ }^{27}$ Cunoscătorii-atît filologii clasici, cît și specialiștii în istoria limbii române și în terminologie-confirmă paternitatea lui C. Aristia în legătură cu forma românească a acestui cuvînt, cf. Rusu (1965, p. 797-800) și, de asemenea, Herescu (2011, p. 387). DLR, s.v., îl consemnează pe C. Aristia printre primii utilizatori ai cuvîntului în română, dar consideră că apariția lui trebuie pusă pe seama etimologiei multiple (franceză, latina, italiană).
} 
de azi. Fenomenul a fost favorizat de lunga tradiție a latinizării Pantheonului elin în culturile apusene. În sfîrșit, procesul a fost încheiat ciclic, prin amplificarea și aprofundarea aspectului lexical la nivelul general al mentalităților, pe de o parte, și al realităților sociale și materiale, pe de altă parte. Locuțiuni, expresii, metafore, structuri morfosintactice și chiar construcții mai ample, care concretizează actele de vorbire, redau mai puțin specificul homeric și mai mult pe cel național, exprimat de geniul intern al limbii-gazdă. În felul acesta, receptarea lumii prin intermediul limbii se schimbă mult, iar ceea ce rămîne din țesătura poemului homeric este firul epic, cu detaliile compoziționale etc. În mod similar s-a procedat și în celelalte culturi din Europa sud-estică, în versiunile sîrbești, croate, bulgare, turcești, ucrainene etc. S-a spus că fenomenul a fost determinat de fondul ancestral comun, indo-european, în varianta balcanică. De fapt, el se regăsește și în transpunerile din limbile și culturile popoarelor iberice și, mai ales, ale celor nordice. Bogata mitologie scandinavă a generat un vocabular și o onomastică ușor adaptabile la fondul Antichității eline.

\section{Concluzii}

3.1. Din punctul de vedere al evoluției limbii literare care a „îmbrăcat” versiunile românești ale poemelor homerice, se disting foarte clar cele trei mari etape din istoria acestor traduceri, deși preluările succesive nu au fost puține. În secolul al XIX-lea, C.D. Aristia și I. Caragiani, întemeietorii tradiției traducerilor din Homer, fac eforturi mari de desprindere din sfera limbii uzuale, prin introducerea unor neologisme (navă etc.), rezultat al calcului lingvistic, al împrumuturilor directe, precum și prin creații interne, bazate pe bogatul sistem derivativ existent în limba națională, prin compuneri și conversiuni îndrăznețe. Baza „noii limbi literare” rămîne, totuși, fondul popular, programatic utilizat în IC, din două motive cunoscute: a) literatura cultă românească și viața culturală, în general, nu erau încă suficient de dezvoltate pentru a furniza materialul lingvistic dintr-o sferă supradialectală, normată și codificată pe stiluri funcționale; b) traducătorii epocii trăiau cu convingerea că lumea homerică era una predominant rurală, primitivă, în multe privințe. După circa o jumătate de secol, lucrurile s-au schimbat mult. Homeriștii români interbelici (G. Murnu, G. Coșbuc, C. Papacostea, E. Lovinescu) au beneficiat de o limbă literară standard deja bine așezată într-un sistem normativ coerent, cu variante poetice bogate, susținute de o literatură națională vizibil conectată la ritmurile europene. De acum, opțiunea pentru formele populare se justifică mai mult prin ideologia traducătorilor, prin dorința acestora de a strunji limbajul poetic, cu elemente încadrabile, totuși, în rigorile stilului înalt. Este epoca celor mai îndrăznețe creații individuale, parțial impuse de nevoia echivalării unor cuvinte și sintagme din limba cu totul specială a originalului, așa-numita „greacă homerică”. A treia și cea mai recentă epocă a traducerilor românești din Homer (sfîrșitul secolului al XX-lea și începutul secolului al XXI-lea) se caracterizează prin cultivarea stilului savant, în care chiar și numeroasele forme populare dobîndesc străluciri de nestemate atent montate în mozaicul lexical al limbajului poetic migălos decantat din toate nivelurile și registrele limbii române. Cuvîntul de ordine în gîndirea lui Hâncu-Diamandescu, dar mai ales a lui D. Slușanschi este fidelitatea-de conținut și de formă-faţă de textul original și, deopotrivă, față de natura limbii proprii. În mod cert, lupta de aproape două secole pentru împămîntenirea poemelor homerice în cultura română a contribuit la perfecționarea limbii literare naţionale.

3.2. Rezultatul final al tuturor tipurilor de opțiuni traductologice discutate mai sus ar trebui să conducă spre o formă care să îmbine contrariile într-o operă literară: fluiditate şi densitate, claritate şi sugestie implicită, concizie și muzicalitate. Pentru aceasta, așa cum se afirmă în mod curent, este necesar ca traducătorul să aibă el însuşi calități de poet. Pe de altă parte, acelaşi truditor trebuie să fie un adevărat savant, specialist în problemele civilizației Greciei antice, cu tot ceea ce presupune aceasta—profunde cunoștințe lingvistice și culturale, o permanentă conectare la studiile moderne în domeniu. În al treilea rînd, se impune factorul relativ obiectiv, poate cel mai important pentru o bună traducere: limba primitoare să fie suficient de matură - prin istoria sa, suficient de bogată și de mlădioasă - prin natura sa, încît geniul 
poetic și cunoștințele de specialitate să-și afle spațiul de manifestare al dublei ipostaze, de tip oximoronic: loialitate și creativitate, față de ambele texte-original și versiune proprie.

3.3. Am verificat aceste adevăruri în primul rînd prin analiza punctuală a nivelului fonomorfologic de utilizare a materialului lexical din versiunile românești ale poemelor homerice. Cînd feluritele distorsiuni, trunchieri, asociaţii insolite ale cuvintelor, mai ales în formele conjuncte, apar în versiunile pentru care a fost folosită formula prozei-textele realizate de I. Caragiani, E. Lovinescu, Hâncu-Diamandescuasemenea abateri de la normă pot reprezenta fenomene ale gramaticii expresive: intr-ascuns, n-a ajuns, nevastă-sa, și-l aşeză etc. Traducerile în versuri înmulțesc considerabil manifestările fenomenului, din necesități metrice. În paginile de mai sus am reținut, pe cît a fost posibil, numai cîteva exemple din această situație. Diferitele concretizări ale eliziunilor, sincopelor, aferezelor, cu variante de realizare în sinaleze și echtlipse, pot fi obligatorii, impuse de întîlnirea a două sau chiar trei unități etimologice, respectiv de uzul coarticulării în tempo lent, care urmează legea naturală a minimului efort în rostirea cuvintelor: parcă, pentru pare că; tat-tău, pentru tatăl tău; ș-om vedea, pentru și vom vedea. Nu am zăbovit asupra redării coerente a sintagmelor uzuale de acest tip, născute din necesitățile eufonice așteptate în vorbirea cotidiană. Am subliniat, în schimb, căutările programatic exagerate ale unor fuziuni, abrevieri, dislocări accentuale care depășesc obligațiile cunoscute și acceptate de vorbitori, reorganizările segmentale aflate la granița dintre uzual și conotativ, de dragul unor efecte inovatoare. Evident, asemenea investigații nu se pot face decît separat în versiunile succesive românești, pe de o parte, față de versiunile grecești de la care s-a pornit, pe de altă parte, căci natura fonetică și morfolexicală diferită a limbilor din cele două rînduri de texte nu lasă loc de echivalări riguroase nici pentru cel mai învățat și mai talentat traducător ${ }^{28}$.

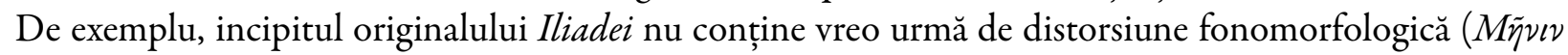

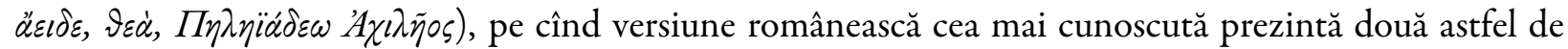

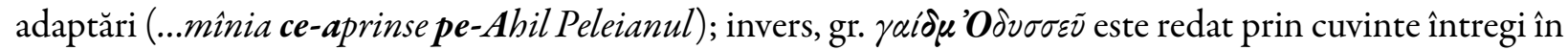
versiunile moderne: Slăvite Odiseu, cf. și fr. Noble Ulisse! În consecință, se impune observația că asemenea fenomene depind mai puțin de diacronia limbii literare, poetice, și mai mult de viziunea echilibrată a traducătorului. Separat de armoniile imitative cerute în mod expres de textul original, de tipul eufoniilor și aliterațiilor, asemenea particularităţi fonomorfologice trebuie reluate într-o analiză sistematică a valorilor expresive ale textelor în discuție, căci și acelea care par fenomene naturale uzuale conferă, în fapt, „un fel de melodie ce se adaugă rostirii cuvintelor" (Demetrios, 1943, 70). Din perspectiva unor traductologi moderni, ritmul este decisiv în orice tip de text echivalat într-o limbă străină. Dacă adevărata traducere înseamnă sesizarea și redarea ritmului şi a melodiei interioare a textului (Dessons \& Meschonnic, 1998, p. 28: «le rythme... l'organisation du mouvement de la parole par un sujet»), atunci versiunile realizate după poemele homerice-eminamente intonate, în forma lor genuină-nu pot fi evaluate valoric decît prin analiza atentă a unor asemenea efecte de detaliu ale formelor ce redau rostirea cuvintelor.

3.4. Într-un fel sau altul, indiferent de formularea expresă a opțiunii, toți traducătorii români au valorificat principiul autohtonizării. Chiar un dușman declarat al latinizării și românizării onomastice, al deturnării Pantheonului Helladei de la rostul ei, ca D. Slușanschi, folosește soluția neaoșismelor, în situații critice, pentru forma, semantismul și locul unui cuvînt sau al unei sintagme în hexametrul românesc. Dincolo de precizia echivalării, științific dovedită, se simte satisfacția găsirii cuvîntului înțelept, mustind de sugestii, căruia îi potențează o anumită strălucire prin măiestrita montură în salba versului frumos și solid rostuit. În plus însă, nici chiar el nu rezistă tentației, cum nu a făcut-o nici C. Papacostea, la vremea lui, de a oferi nimfelor homerice chipul Zînei Zînelor (CP), ba chiar și „sălaşul... Cosînzenei” (DS) de pe meleagurile mioritice. Și nici nu se putea altfel, cel puțin la nivelul lexicului uzual, din cel puțin trei motive, aflate la

\footnotetext{
${ }^{28}$ Nici chiar adaptarea poemelor din greaca homerică în greaca modernă nu permite echivalarea totală a unor asemenea particularități. Versiunea realizată de Nikos Kazantsakis în katharevousa, greaca modernă îngrijită, pare mai plină de asemenea reorganizări ale normelor coarticulării decît textul străvechi, de tip popular, deci mai liber de orice fel de constrîngeri fonomorfologice.
} 
îndemîna oricui:

a) Textul homeric rămîne, cum am mai mai spus-o, un model de arhaicitate, oralitate, tradiționalism, simplicitate, naivitate, chiar primitivism al reacțiilor umane, pe alocuri, ridicate la rang de universalitate printr-o operă artistică desăvîrșită. Sensibilitățile, orgoliile, temerile, atitudinile lumii homerice sînt ingenue și profund umane, în acelaşi timp, iar cuvintele prin care și le exprimă nu complică inutil această realitate. În greaca homerică, se spune despre aheul sau troianul nou-născut că „vede soarele / lumina zilei" (Il., IV, 1112) ${ }^{29}$, ca în limba românească vie, populară, dar ca și în limba oricărei alte comunități umane de pe pămînt.

b) Limba română literară a fost legată strîns de variantele populare, de la începuturile ei și pînă în actualitatea cea mai acută, orice vor fi zicînd specialiștii. O poveste țesută într-un idiom exclusiv poeticdecantat din toate sursele vorbirii reale ale epocilor de geneză epică-nu putea fi re-făcută în limbile moderne decît prin replici ale acesteia, concepute după aceeași structură.

c) În orice traducere din lume, sînt frecvente situațiile în care „cuvîntul potrivit”, menit să compenseze forme, sensuri și construcții gramatical-pragmatice din limba-bază, nu poate fi găsit decît în cotloanele fondului național popular. Puține sînt abdicările de la redarea corectă și sugestivă în favoarea celei considerate îngrijite, adică în varianta înaltă, dar seacă a limbii literare, ștearsă, lipsită de adecvarea la spiritul textului primar. Or, toate acestea sînt manifestări ale unei autohtonizări discrete, desigur, poate chiar involuntare și inconștiente, dar implacabile și salvatoare.

3.5. Versiunile românești ale poemelor homerice confirmă un paradox al traducerilor, remarcat deja de mult timp în spații lingvistice cu bogată experiență în domeniu: marile capodopere literare ale omenirii nu îl anihilează pe traducătorul care și-a propus să reziste pînă la capăt, ci, dimpotrivă, îl întăresc și îi stimulează resursele creatoare, hrănite din solul spiritualității neamului său, în bună parte. În termenii științei moderne a traductologiei, asta înseamnă că, în relația cu Iliada și Odiseea, nici nu poate fi vorba despre „invizibilitatea traducătorului”, cum ar cere-o unele teorii recente (cf. Venutti, 1995, p. 306). Păstrînd respectul față de stranietatea textului original și față de străinul care îl reprezintă (Berman, 1991), versiunile românești permit ceea ce generația actuală de traductologi numește „identificarea vocii traducătorului” (Hermans, 1996). Mai timidă la primii traducători din istoria românească a versiunilor homerice (CA și IC), bine strunită la cei mai recenți (HD și, mai ales, DS), această „voce secundă”, care însoțește peste tot discursul din textul original ${ }^{30}$, se face simțită fără opreliști în tălmăcirile GC și GM, de valori diferite, desigur, dar deopotrivă asumate personal.

3.6. În legătură cu manifestările relației limbă-gîndire în procesul traducerilor din textele homerice, trebuie să spunem că adaptările la specificul limbii primitoare, oricît de masive, nu sînt niciodată atît de copleșitoare, încît să deturneze în vreun fel esența originalului grecesc. Cele două epopei homerice sînt construcții mult prea puternice, solid durate „la foc continuu” și cu forță de iradiere întinsă pe milenii de circulație în posteritate, ca să poată fi umbrite de haina națională a traducerilor, chiar programatic autohtonizante.

3.7. Ceea ce oferă aceste poeme nu este doar matricea unei culturi şi civilizații pe care se întemeiază lumea modernă, ci și modelul făuririi unor limbi naționale de inaltă ținută filosofică și artistică. Afirmația curentă, menționată mai sus cu privire la statutul de poet deja consacrat cerut unui bun traducător din Homer (cazurile unanim recunoscute în cultura noastră fiind GC și GM) are și o reciprocă, în istoria receptării acestor traduceri: unii cărturari au devenit poeți lucrînd pe textele homerice. Simplitate și puritate, profunzime și înălțimi astrale, localism și universalitate - acestea sînt cîteva dintre elementele care configurează limba literară naţională a traducătorilor, trecută prin complicatul decantor al poemelor homerice.

\footnotetext{
${ }^{29}$ Cf. și Il., IV, 724, versul în care Menelau identifică viața cu lumina soarelui.

${ }^{30}$ Cercetători din școala reprezentată de Helmans au realizat chiar diagrame care înregistrează prezența acestei voci a „dublurii autorului" originalului, cf. Schiavi (1996).
} 


\section{Bibliografie}

\section{A. Surse}

\section{A.1. Ediții de text}

Il-A-H-C = Homers, Ilias, K.F. Ameis-C. Hentze-P. Camer, 2 vol. ( 4 facs), ed. 4-8, Leipzig: Teubner, 1905-1932. Reimpr.: Hidesheim, 1970.

Il-M-A = Homer, Iliad, by Monro, D. B. \& Alen, Th. W., Vol. I-II, Clarendon Press, Oxford, $1966^{3}$.

Il-PM = Homère, Iliade, Tomes I-IV. Ed. Paul Mazon et al., Paris: Les Belles Lettres, 1974.

Od-Murray $=$ Homer, The Odyssey with an English Translation by A. T. Murray, Ph.D. in two volumes, Harvard University Press, Cambridge, MA; William Heinemann, Ltd., London, 1919.

PP-I = Iliad online version from the Perseus Project (PP) translation and hyperlinks. (Homeri Opera in five volumes. Ed. D. B. Monro/Th. W. Allen, Oxford: University Press, 1920.)

$\mathrm{PP}-\mathrm{O}=$ Odyssey online version from the Perseus Project (PP) translation and hyperlinks (Homer. The Odyssey with an English Translation by A.T. Murray, PhD in two volumes. Cambridge, MA.: Harvard University Press; London: William Heinemann, Ltd. 1919.).

\section{A.2. Traduceri în română}

\section{A.2.1. Iliada}

CA-I = Omer, Iliada, Tom I. Rapsodiile I-VI. Traducere de D. C. Aristia, Tipografia lui Eliad, București, 1837. (versuri albe) DS-I = Homer, Iliada. Tradusă în hexametri, cu o postfață, bibliografie și indici de Dan Slușanschi și ilustrată de Mihai Coșulețu, Editura Humanitas, București, 2012.

GM-I = Homer, Iiada. În românește de George Murnu. Premiul cel Mare al Academiei Române [București]: Cultura Naţională, [1920].

GMD-I = Homer, Iliada . Traducere în metru original de George Murnu. Studiu introductiv și note de D. M. Pippidi. Ediție definitivă. Editura pentru Literatură Universală, București, 1967.

$\mathrm{GMF}_{1}-\mathrm{I}=$ Homer, Iliada. Traducere în metru original de George Murnu. Îngrijirea ediției, studiu introductiv, note și glosar de Liviu Franga, Editura Univers, București, 1985.

$\mathrm{GMF}_{2}-\mathrm{I}=$ Homer, Iliada. Traducere în metru original de George Murnu. Ediția a II-a, revizuită și adăugită, cu un studiu introductiv nou, note, notă asupra ediției şi glosar de Liviu Franga, Editura Fundației Culturale, București, 1995.

HD-I = Homer, Iliada. Traducere [în proză] de Radu Hâncu, Sanda Diamantescu. Vol. I-II, Editura Minerva, București, 1981. RH-I = Homer, Iliada. Traducere de Radu Hâncu. Cuvînt înainte de Gabriela Hâncu, Editura Mondoro - Editura Gramar, București, 2011.

\section{A.2.2. Odiseea}

CP-O = Homer, Odysseia, I-XII. Traducere de Cezar Papacostea, 1929. Introducere, notă asupra ediției, note și indice de Ioana Costa, Editura Muzeului Literaturii Române, București, 2013.

DS-O = Homer, Odysseia. Traducere în hexametri de Dan Slușanschi, Editura Paideia, București, 2009.

DS-Or = Homer, Odysseia. Traducere în hexametri, cu postfață, bibliografie și indici de Dan Slușanschi și ilustrată de Dan Rădvan. Revizuiri și completări de Octavian Gordon și Francisca Băltăceanu, Editura Humanitas, București, 2012.

EL-O = Homer, Odiseea. Traducere în proză de E. Lovinescu. Cuvînt înainte și note de Elena Mazilu-Lovinescu, Editura MondoRo, București, 1995.

EL-Or ${ }_{1}=$ Homer, Odiseea. [Traducere de Eugen Lovinescu. Text revizuit și note de Traian Costa. Studiu introductiv și indice de Mihai Nasta], Editura pentru Literatură, București, 1963. (Ed. I: 1935)

EL-Or ${ }_{2}=$ Homer, Odiseea, Vol. I-II. Traducere de Eugen Lovinescu. Text revizuit și note de Traian Costa. Prefaţă de Venera Antonescu, Editura Tineretului, București, [1966].

EL-Or ${ }_{3}=$ Homer, Odiseea. Traducere de E. Lovinescu. Ediție revizuită și postfață de Traian Diaconescu, Editura Saeculum I. O., București, 1996.

EL-Or 5 = Homer, Odiseea (Ediția a 5-a). Traducere de E. Lovinescu. Studiu introductiv și indice de Mihai Nasta. Text revăzut şi Note asupra ediției de Traian Costa, Editura pentru Literatură, București, 1963.

GC-O = Homer, Odiseea, vol. I-II. Traducere de George Coșbuc. Ediție îngrijită de I. Sfetea și Șt. Cazimir. Prefață de Șt. Cazimir, Editura pentru Literatură, București, 1966. (Mss. 1916).

GM-O = Homer, Odissea. Traducere de George Murnu. Studiu introductiv și note de Adrian Pârvulescu, Editura Univers, București, 1979.

GM-Od = Homer, Odiseea . Traducere de George Murnu. Studiu introductiv și note de D. M. Pippidi. Ediție definitivă, Editura Univers, București, 1971. (Ed. I: 1928)

\footnotetext{
*Referințele bibliografice au în vedere forma integrală a acestui studiu, care continuă partea publicată în numărul 2/2015 al revistei „Diacronia”.
} 
IC-O = Odiseea. Batrachomyomachia - Războiulşsoarecilor cu broaștele. Traducere în proză, note și prezentări de Ioan Caragiani. Argument. Note asupra ediției de Ion Acsan, Editura MondoRo, București, 2011. (Ed. I - H. Goldner, Iași, 1876)

\section{B. Referințe}

Acsan, I. (1984). Constelația corifeilor..., Editura Cartea Românească, București.

Ameis, K. F. \& Hentze, C. (1965a). Anhang zu Homers Ilias, ediţia a IV-a, vol. I-II, De Gruyter, Amsterdam.

Ameis, K. F. \& Hentze, C. (1965b). Anhang zu Homers Odysee, ediția a IV-a, vol. I-II, De Gruyter, Amsterdam.

Aristotel (1965). Poetica, traducere de D. M. Pippidi, Editura Academiei, București.

Bailly, C.A. (1950). Dictionnaire grec-français, Hachette, Paris.

Barbu, N. I.; \& Piatkowski, A. (1978). Scriitori greci și latini, Editura Științifică și Enciclopedică, București.

Bârlea, P.Gh. (2008). Limba poveștilor populare românești, Editura Academiei Române, București.

Bârlea, P. Gh. (2014). Româna literară în fața poemelor homerice, în: Bârlea, P. Gh. \& Toma, F. R. (coord.), Culturăși comunicare, Editura Muzeul Literaturii Române, București, p. 27-31.

Bârlea, P. Gh. (2015a). Autohtonizarea textelor homerice în versiunile sud-est europene, în: Spăriosu, L. \& Popovici, V. (coord.), Communication, Culture, Creation: New Scientific Paradigms, Europa Press, Novi Sad - Arad, p. 23-37.

Bârlea, P. Gh. (2015b). Ipostaze ale homerismului în literatura universală, în „Litere”, XVI, 3, (180), p. 67-69.

Bârlea, P.Gh. (2015c). Poemele homerice în veșminte româneşti. O analiză diacronică (I), în „Diacronia”, nr. 2, 17 iul., art. A18, CrossRef.

Berman, A. (1991). La traduction et la lettre ou l'auberge du lointain, Seuil, Paris.

Camps, W.A. (1980). An Introduction to Homer, Oxford University Press, Oxford.

Chantraine, P. (2009). Dictionnaire étymologique de la langue grecque. Histoire des mots, vol. I-II, Klincksieck, Paris.

Demetrios din Faleron (1943). Tratatul despre stil, traducere, introducere și comentar de C. Balmuș, Tipografia Alexandru A. Țerek, Iași.

Dessons, G. \& Meschonnic, H. (1998). Traité du rythme. Des vers et des proses, Dunod, Paris.

DLR = Dicționarul limbii române, ediție anastatică după Dicționarul limbii române (DA) și Dicționarul limbii române (DLR), tomul XV, Editura Academiei, București.

Eftimiu, V. (1996). Opere, vol. 18, Memorialistică. Publicistică literară, ediție și note de Constantin Mohanu, Editura Minerva, București.

Eminescu, M. (1952). Opere, vol. IV, Poezii postume. Anexe. Introducere. Tabloul edițiilor, ediție critică îngrijită de Perpesiccius, Editura Academiei R.P.R, București.

Eminescu, M. (1958). Opere, vol. V, Poezii postume. Anexe. Note şi variante. Exerciţii şi moloz. Addenda şi corrigenda. Apocrife. Mărturii, indice, ediție critică îngrijită de Perpessicius, Editura Academiei R.P.R., Muzeul Literaturii Române, București.

Foucault, M. (1998). Ordinea discursului. Un discurs despre discurs, traducere de Ciprian Tudor, Eurosong \& Book, București.

Georgescu, N. (2005). Homer - contemporanul nostru, în: Recife. Eseuri de oceanografie, Editura „Floare Albastră”, București, p. 11-51.

Herescu, N.I. (1929). Homer: Iliada. În românește de George Murnu (Cultura națională), în: „Revista Clasică. Orpheus. Favonius", V, I, 1-4, p. 68-70.

Herescu, N.I. (2011). Destin fără moarte (Pentru clasicism), ediție îngrijită, notă asupra colecției, notă asupra ediţiei, studiu introductiv de Liviu Franga, Editura Muzeul Literaturii Române, București.

Hermans, T. (1996). The Translator's Voice in Translated Narrative, în „Target”, vol. 8/1, p. 23-48, CrossRef.

Kirk, G. (coord.) (1985-1993). The Iliad: A Commentary, vol. I-VI, Cambridge University Press, Cambridge, CrossRef.

Lascu, N. (1974). Clasicii anticii în România, Editura Dacia, Cluj-Napoca.

Lord, A. (1960). The Singer of Tales, Harvard University Press, Cambridge, MA.

Lovinescu, E. (2012). O privire asupra clasicismului, ediție îngrijită, studiu introductiv, notă asupra ediției, note și comentarii de P. Gh. Bârlea, Editura Muzeul Literaturii Române, București.

Marinescu-Himu, M. \& Piatkowski, A. (1972). Istoria literaturii eline, Editura Științifică, București.

Meister, K. (1966). Die homerische Kunstsprache, ediția a II-a, Teubner Verlag, Darmstadt - Leipzig, CrossRef.

Parry, M. (1971). The Making of Homeric Verse, în: The Collected Papers of Milman Parry by Adam M. Parry, Oxford University Press, Oxford.

Platon (1983). Opere, vol. IV, ediție îngrijită de Petru Creția, Editura Științifică și Enciclopedică, București.

Risch, E. (1973), Wortbildung der homerischen Sprache, ediția a II-a, De Gruyter \& Co., Berlin - New York, Tome II: Syntaxe (1997), CrossRef.

Rusu, V. (1965). C. Aristia și problemele cultivării limbii la mijlocul secolului al XIX-lea, în: Omagiu lui Alexandru Rosetti, Editura Academiei, București.

Schiavi, G. (1996). There is Always a Teller in a Tale, în „Target”, vol. 8/1, p. 1-21, CrossRef.

Stoica, G. (2012). Afect și afectivitate. Conceptualizare și lexicalizare în româna veche, Editura Universității din București, București.

Ursu, N.A. (1962). Formarea terminologiei științifice românești, Editura Științifică, București.

Wace, A.J.B. \& Stubbings, F.H. (1963). A Companion to Homer, Macmillan \& Co., London - Toronto. 
Venutti, L. (1995). The Translator's Invisibility: A History of Translation, Routledge, London / New York. Whitman, C. H. (1958). Homer and the Homeric Tradition, Harvard University Press, Cambridge, MA. 